\title{
HOXD8 exerts a tumor-suppressing role in colorectal cancer as an apoptotic inducer
}

Mohammed A. Mansour1, Takeshi Senga2

${ }_{1}$ Biochemistry Division, Department of Chemistry, Faculty of Science, Tanta University, Tanta 31527, Egypt

${ }_{2}$ Division of Cancer Biology, Nagoya University Graduate School of Medicine, 65 Tsurumai, Showa, Nagoya, 466-8550 Japan

Address correspondence to:

Mohammed A. Mansour; Biochemistry division, Department of Chemistry, Faculty of Science, Tanta University, Tanta 31527, Egypt; E-mail: biomansour@hotmail.com

Running title: HOXD8 suppresses colorectal cancer progression

Keywords: Colorectal Cancer; HOXD8; homology modeling; TCGA; STK38; MYC; Apoptosis

Conflict-of-interest statement: The authors declare that they have no conflict of interest.

The data sharing statement: No additional data are available. 


\begin{abstract}
Homeobox (HOX) genes are conserved transcription factors which determine the anteriorposterior body axis patterning. HOXD8 is a member of HOX genes deregulated in several tumors such as lung carcinoma, neuroblastoma, glioma and colorectal cancer (CRC) in a context-dependent manner. In CRC, HOXD8 is downregulated in cancer tissues and metastatic foci as compared to normal tissues. Whether HOXD8 acts as a tumor suppressor of malignant progression and metastasis is still unclear. Also, the underlying mechanism of its function including the downstream targets is totally unknown. Here, we clarified the lower expression of HOXD8 in clinical colorectal cancer vs. normal colon tissues. Also, we showed that stable expression of HOXD8 in colorectal cancer cells significantly reduced the cell proliferation, anchorage-independent growth and invasion. Further, using The Cancer Genome Atlas (TCGA), we identified the genes associated with HOXD8 in order to demonstrate its function as a suppressor or a promoter of colorectal carcinoma. Among inversely related genes, apoptotic inhibitors like STK38 kinase and MYC were shown to be negatively associated with HOXD8. We demonstrated the ability of HOXD8 to upregulate executioner caspases $6 \& 7$ and cleaved PARP, thus inducing the apoptotic events in colorectal cancer cells.
\end{abstract}




\section{Introduction}

The homeobox (HOX) genes are developmental regulatory genes which give cells positional information in embryogenesis [1]. There is a common sequence element of $180 \mathrm{bp}$ encoding for highly conserved 60-amino-acid homeodomain called the homeobox. This binding ability of HOX genes to DNA is conferred by the homeodomain to act as transcription factors (TF) [2]. HOXA, HOXB, HOXC and HOXD, found on separate chromosomes are forming the four gene clusters of 39 HOX genes in mammals [3]. In a highly coordinated manner, the HOX genes are expressed spatio-temporally during emryogenesis to build up regional identities along the anteriorposterior body axis [4]. The role of HOX genes to regulate the differentiation or maturation in organs and tissues is not exclusive to the embryo. It has recently become apparent that the patterns of expression of HOX genes are organ- or tissue characteristic not only in the embryo but also in the adult or post-natal body [5]. Furthermore, aberrant expression of particular HOX genes has been reported in several types of carcinomas suggesting that HOX genes are involved in oncogenesis and malignant progression [6]. For instance, expression of 39 HOX genes was deregulated in lung, breast, oral and esophageal cancers and melanoma [7-11]. Other reports also showed differences in expression patterns of HOX genes in cancers of kidney, colon, prostate, and uterus [12-15].

Nine genes (HOXD1, HOXD3, HOXD4, and HOXD8-13) constitute the HOXD cluster and are positioned sequentially from 3'to 5', with HOXD1 at the 3' end and HOXD13 the 5' end. Among HOXD cluster, induction of HOXD8, HOXD9, HOXD10 or HOXD12 induces growth arrest and neuronal differentiation with downregulation of cell cycle-promoting genes and upregulation of differentiation genes [16]. Nevertheless, other HOXD genes like HOXD1, HOXD3, HOXD4, HOXD11 and HOXD13 have no or partial effects on neuroblastoma cell proliferation or differentiation [16]. These findings highlight the distinct functions of HOXD genes in the induction of cancer cell differentiation.

In colorectal cancer (CRC), HOXD8 expression was downregulated in clinical cancer tissues especially in metastatic foci as compared to primary tissues [1]. Also, HOXD8 is among the downstream restricted targets of miR-196a which has a potential oncogenic function in colorectal cancer. Depletion of HOXD8 mRNA levels by miR-196a in colorectal cancer results in inhibition of differentiation and promotion of oncogenic features [17]. In this sense, lowered expression of HOXD8 in colorectal cancer tissues fascinated us to understand the role of 
HOXD8 in CRC and explain whether HOXD8 may act as a tumor suppressor of malignant progression and metastasis.

In the current study, we demonstrated that HOXD8 expression suppresses colorectal cancer cell proliferation, colony forming capacity and invasion. TCGA analysis showed that HOXD8 is negatively associated with STK38 and MYC which have a negative impact on apoptotic pathways rendering infinite cancer cell growth. Thus, expression of HOXD8 downregulated the expression of MYC mRNA and upregulated the apoptotic marker proteins. Our results uncover for the first time, the relationship between HOXD8, STK38 and MYC in apoptosis of cancer cells. Further studies are warranted to elucidate the mechanistic insights of this association and to uncover more downstream targets of HOXD8 in CRC and other types of cancer.

\section{Materials and Methods}

\subsection{Culture cells and antibodies}

Colorectal cancer cells, HCT116, DLD-1 and HT29 cells, were obtained from American Type Culture Collection (ATCC) and cultured in DMEM (for HCT116 and HT29) or RPMI (for DLD-1) supplemented with 10\% fetal bovine serum (FBS) (EQUITEC, Hen-dra, Australia). We authenticated the cancer cells by short tandem repeat analysis using gene print ${ }^{\circledR} 10$ system (Promega,Madison, WI). The antibodies used were purchased from the following manufacturers: anti-E-cadherin antibody, BD Biosciences (San Jose, CA); anti-B-actin antibody, Sigma-Aldrich, St. Louis,MO, USA; anti-GFP antibody, Neuro Mab (Davis,CA); anti-palladin, as previously produced [18,19]; anti-cleaved caspase-6 (Asp162), anti-cleaved caspase-7 (Asp198), anti-cleaved PARP (Asp214) , anti-phospho-ERK1/2 and anti-phospho-AKT (Ser473) antibodies, cell signaling technology®, Danvers, MA, USA.

\subsection{Patients and ethical statement}

Normal and colorectal cancer patients who went through surgery at Nagoya University graduate school of Medicine hospital were participating in this study. For the detection of HOXD8 mRNA expression levels in normal vs. colorectal cancer specimens (stages II-IV collected from male and female patients (Age 30-60 yr).), qRT-PCR analysis was performed. Written informed consents were provided from the participating patients and the study plan was approved by the institutional review board of the university as conformed to the standards set by the Declaration of Helsinki. 


\section{3. $\quad q R T-P C R$ (Quantitative Real-Time PCR)}

Endogenous mRNA from normal colon and colorectal cancer samples was extracted using the RNeasy mini kit (Qiagen, Venlo, Netherlands), and then the corresponding cDNAs were synthesized using primescript Reverse Transcriptase (TAKARA, Tokyo, Japan). The normal colon and colorectal cancer tissues were obtained from patients who underwent surgery at the Nagoya University Hospital. The real time PCR was performed using the SYBR Premix Ex Taqтм II (TAKARTA), and the Thermal Cycler Dice тм Real Time System TP800 (TAKARA) was utilized for the analysis and quantification of the gene expression. The relative mRNA level of each gene was normalized to GAPDH. The sequences of primers used to amplify each gene were 5'-AGGTGGAGGAGTGGGTGTCGCTGTT-3' and 5'-CCGGGAAACTGTGGCGTGATGG-3' (GAPDH), 5'-GTTTTGAACCGCCCTTGTAA-3' and 5'-GTGAGGCTATCGCTTTCCTG-3' (HOXD8), and 5'CATCAGCACAACTACGCAGC-3' and 5'-GCTGGTGCATTTTCGGTTGT-3' (MYC).

\subsection{Analysis of Oncomine data}

To determine the expression pattern of HOXD8 in colorectal cancer, the datasets in Oncomine, a cancer microarray database (https://www.oncomine.org), were utilized. In brief, HOXD8 gene was queried in the database and the results were filtered by selecting colorectal cancer and Colon Cancer vs. Normal Analysis. The data was displayed by using Column chart. P-values for each group were calculated using student t-test. Other details of standardized normalization techniques and statistical calculations can be found on the Oncomine (https://www.oncomine.org/resource/login.html).

\section{5. $\quad c D N A$ constructs}

Complementary DNA (cDNA) for the human gene; HOXD8 was amplified by Polymerase Chain Reaction (PCR) from a cDNA library of HeLa cells. A cDNA library simply contains sequences that are complementary to mRNAs transcribed from the human genome. The cDNA was then cloned into the pQCXIP vector (TAKATA, Tokyo, Japan) with an N-terminal green fluorescence protein (GFP) tag as described previously [20]. Hence, GFP or GFP HOXD8 clones were ready for retroviral infection into the cancer cells.

\subsection{Establishment of stable cell lines}


Colorectal cancer cells, HCT116, DLD-1 and HT29 that constitutively expressed GFP and GFP HOXD8 were generated by retrovirus infection. The pQCXIP vector encoding GFP or GFP HOXD8 was transfected into the human embryonic kidney (HEK) 293 cells in combination with the pVPack-GP and pVPack-Ampho vectors (Stratagene, Tokyo, Japan) using Lipofectamine 3000 (Invitrogen, Carlsbad, CA). After $48 \mathrm{~h}$ transfection, we collected the supernatant and were added to HCT116, DLD-1 or HT29 cells with $2 \mathrm{\mu g} / \mathrm{mL}$ polybrene (Sigma-Aldrich, St. Louis, MO, USA), and infected cells expressing each vector were selected with $1 \mathrm{\mu g} / \mathrm{mL}$ puromycin (SigmaAldrich, St. Louis, MO, USA) for three constitutive days as described previously [21].

\subsection{Western blot analysis}

Western blotting analysis was conducted as described previously [22]. The cellular protein lysates cultured with GFP or GFP HOXD8 were prepared by incubating the cells with 2X sample buffer (1M Tris-HCl ( $\mathrm{pH}$ 6.8), SDS, Glycerol, BPB (bromophenol blue, 2Mercaptoethanol) for $5 \mathrm{~min}$ at $100^{\circ} \mathrm{C}$ then were kept on ice till use. The Lowry protein assay (Thermal Scientific) was used to determine the protein concentration in each sample. Fifteen to twenty micrograms of the total protein from each sample were used for SDS-polyacrylamide gel electrophoresis (PAGE) and transferred to a polyvinylidene difluoride (PVDF) membranes (Millipore, Billerica, MA, USA) electrophoretically. In order to block nonspecific binding to proteins, the membranes were incubated in phosphate buffered saline containing 1\% non-fat skim milk for $1 \mathrm{~h}$ at room temperature. Then, primary antibody was properly diluted and incubated with the membrane at $4^{\circ} \mathrm{C}$ overnight. The membranes were then washed with TBS-T buffer (10 mM Tris-HCl pH 7.4, $150 \mathrm{mM} \mathrm{NaCl}$, 0.05\% Tween 20) for 10 min 3 constitutive times and incubated with HRP-labeled secondary antibodies for $1 \mathrm{~h}$. Finally, the membranes were washed with TBS-T buffer for 10 min three times. The protein bands' signals were detected with the ECL system (Nacalai tesque, Kyoto, Japan). The signals' intensities were detected using Light Capture II equipped with CS analyzer (ATTO Corp., Tokyo, Japan).

\subsection{MTT cell proliferation assay}

The MTT cell proliferation assay is a colorimetric assay for assessing the proliferation rate of the cells. The assay depends on the activity of NADPH-dependent cellular oxidoreductase enzymes which reflect the number of viable cells. These enzymes are able to reduce the tetrazolium dye MTT 3-(4,5-dimethylthiazol-2-yl)-2,5-diphenyltetrazolium bromide to its insoluble form, formazan, forming a purple color indicative of the number of cells present. The cells were infected with retrovirus for constitutive expression of GFP or GFP HOXD8 and 
cultured in 96-well plates. Then, after establishment of the stable cell lines, MTT assay was conducted from day 0 , and the number of the cells at the indicated time points were estimated using the Cell Count Kit-8 (Dojindo, Tokyo, Japan) as described previously [23].

\subsection{Colony formation assay}

The colony forming capacity or anchorage-independent growth assay was performed as described previously [24]. Briefly, HCT116, DLD-1, HT29 cells ( 1 x 104) were cultured with 0.36\% agar in 10\% FBS DMEM and overlaid onto a $0.72 \%$ agarose layer in 6 -well plates. After 2 weeks of incubation at $37^{\circ} \mathrm{C}$, growing colonies in five randomly selected fields were counted. Three independent experiments were performed to assure the validity of the results and the data are shown as the mean $\pm \mathrm{SE}$.

\subsection{Cancer cell invasion assay}

To assess the cancer cell invasiveness using Boyden chambers, a filter (8- $\mu \mathrm{m}$ pore size, 6.5-mm membrane diameter) was pre-coated with matrigel overnight. Then, 2 x 105 HCT116 cells or $2 \mathrm{x}$ 104 DLD-1 cells were seeded onto the upper surface of the chamber with DMEM and 0.1\% BSA (starvation) while the lower chamber was filled with DMEM and 10\% FBS (chemo-attractant). After $24 \mathrm{~h}$ incubation at $37^{\circ} \mathrm{C}$, he cells were fixed with $70 \%$ methanol and stained with $0.5 \%$ crystal violet. The cells which invaded the lower surface of the filters were counted in 5 randomly selected fields as described previously [25]. Three independent experiments were performed.

\subsection{Homology modeling by the server SWISS-MODEL}

The server searches for the template with Blast and HHBlits against the SWISS-MODEL template library and the templates with the highest quality have been chosen for model building. Models are built based on the target (HOXD8)-template alignment using ProMod3. Coordinates conserved between the target and the template are copied from the template to the model. The geometry of the resulting model is regularized by using a force field. Also, homooligomeric structure of the target protein (HOXD8) is predicted based on the analysis of pairwise interfaces of the identified template structures. More details of the model building, model quality estimation, ligand modeling, oligomeric state conservation can be found on the server Swiss-model. 


\subsection{TUNEL assay}

The Terminal DNA transferase-mediated dUTP nick end labeling (TUNEL) assay was performed to determine in situ apoptotic DNA breaks by using the detection kit (Roche, Basel, Switzerland) according to the manufacturer's protocol. HCT116, DLD-1 and HT29 cells expressing FLAG or FLAG HOXD8 were established by retroviral infection. Cells attached to glass slides in culture dishes were subjected to the assay, imaged with fluorescence microscopy, and the percentage of TUNEL-positive cells was evaluated.

\subsection{Statistical analysis}

All data presented are as the mean \pm Standard Error (SE). Statistical analysis for cancer cell proliferation, and colony forming capacity was performed by unpaired t-test using Microsoft Office Excel 2013. $P$ values of $<0.05$ were considered statistically significant.

\section{Results}

\subsection{HOXD8 mRNA is reduced in clinical colon cancer samples and HOXD8 expression reduces cancer cell proliferation in vitro}

In order to unravel the function of the homeobox D8 in colorectal cancer, we first examined HOXD8 mRNA levels in human normal colon and colorectal cancer specimens by qRT-PCR analysis. The analysis revealed a significant reduction in mRNA levels of HOXD8 in 18 human colorectal cancer tissues with 9 samples showing more than 5-fold decreases in HOXD8 mRNA compared with the normal controls (Fig. 1A). In parallel, we analyzed seven independent datasets from Oncomine database. The results showed that HOXD8 mRNA was differentially expressed in colon carcinoma in comparison to normal lung tissues. Among 40 samples, HOXD8 Expression in Skrzypczak Colorectal 2 dataset showed around 8 fold reduction in colon cancer as compared to the normal colon (Fig. 1B). These observations suggested that HOXD8 expression was reduced in colon cancer tissues. We next examined the expression level of HOXD8 in various colorectal cancer cell lines. qRT-PCR analysis showed that HOXD8 was expressed relatively high in SW620 and SW1080 cancer cells while expressed relatively low in HT29, DLD-1 and HCT116 cells (Fig. 1C).

Then, we examined the effects of the exogenous expression of HOXD8 on colorectal cancer cells showing comparably lower expression of HOXD8. We established HCT116, DLD-1 and HT29 cells that constitutively expressed GFP or GFP HOXD8 by retrovirus infection. The level of 
exogenously expressed GFP or GFP HOXD8 was identified by antibody against GFP tag (Fig. 1D). To determine whether HOXD8 expression had any effect on cancer cell proliferation in vitro, we performed a cell proliferation assay. As shown in Fig. 1E, ectopic expression of HOXD8 had a suppressive function on the proliferation of HCT116, DLD-1 and HT29 cells. In order to further assess the proliferative capacity of the cells with respect to apoptosis, we employed the Terminal DNA transferase-mediated dUTP nick end labeling (TUNEL) assay. After imaging the cells under fluorescence microscope, HOXD8 expression in HCT116, DLD-1 and HT29 cells significantly increased the percentage of in situ apoptotic DNA breaks indicating induction of apoptosis and suppression of cell proliferation (Supplementary Fig. 1A).

The capability of cancer cells to exhibit anchorage-independent cell growth (colony formation capacity in semisolid media), has been considered to be a fundamental process in cancer biology. This is because it has been associated with cancer cell aggressiveness in vivo such as tumorigenic and metastatic potentials, and also used as a marker for in vitro cancer transformation. To explore whether HOXD8 expression inhibits the anchorage-independent growth of colorectal cancer cells, HOXD8-expressing cells were cultured in soft agar. After two weeks, the number of colonies and average colony size were determined. The results showed a significant suppression of the growth of HOXD8-expressng cells in the absence of cell adhesion

to the extracellular matrix (Fig. 2A, 2B and 2C). These results show that HOXD8 has a suppressive effect on cancer cell proliferation and colony forming capacity.

\subsection{Exogenous expression of HOXD8 inhibits cancer cell invasion}

Cancer cell invasiveness and metastatic ability is a multistep process that comprises cell adherence modulation, extracellular matrix degradation, migration and proliferation at a secondary site; finally, tumor cells must also stimulate angiogenesis to attain increased growth requirements. Therefore, it is very important to measure the invasive ability of cancer cells to assess the tumor suppression character of certain genes. The Matrigel 'chemoinvasion' assay is a useful tool for this purpose and for screening of anti-invasive agents. One major simplification of this assay is the use of a reconstituted membrane 'Matrigel', which when applied in the Boyden chamber, cancer cell invasive potential can be rapidly quantified. This in vitro invasion assay was found to correspond to metastatic potential in vivo [26].

To evaluate cell invasion in HOXD8 expressing cells, we first observed the morphology of several colorectal cancer cells upon constitutive expression of HOXD8. As shown in Fig. 3A, HOXD8 expression rendered the cells more spherical in shape rather than fibroblastic 
(fibroblast-like) cells which are bipolar or multipolar, have elongated shapes, and grow attached to a cell surface substrate. Next, we used Matrigel-coated Boyden chambers and DLD-1 cells expressing either GFP or GFP HOXD8 were seeded in the upper chamber, and invading cells were counted $24 \mathrm{~h}$ later in the lower surface. A significant reduction in invading cells was observed with HOXD8 expression as shown in Fig. 3B.

\subsection{Homology Modelling of HOXD8}

So far, we showed the function of HOXD8 in colorectal cancer cells to suppress the cancer cells' proliferation, colony formation and invasion. Due to the lack of 3-dimensional structure of HOXD8 in literature, we used the server SWISS-MODEL to theoretically expect the more likely structure of HOXD8. The SWISS-MODEL template library (SMTL version 2017-01-06, PDB release 2016-12-30) was searched with Blast [27] and HHBlits [28-31] for evolutionary similar structures which match the target sequence of HOXD8. The template protein was found to be 2r5z.1.C which is a homeotic protein Sex combs reduced with 65.79 sequence identity and 0.51 sequence similarity (Fig. 4A and 4B). The HOXD8 has N-terminus residues spanning around 290 amino acids that through our analysis, the software predicted formation of three helices after comparing 181-256 amino acids residues with the template protein (Fig. 4C and 4D). But, the remaining residues contain abnormally abundant poly-A and poly-P that hindered the formation of any stable ternary structure.

\subsection{HOXD8 expression downregulates palladin and upregulates $E$-cadherin}

Due to the observed role of HOXD8 to suppress cancer cell invasiveness and modulate the fibroblast like cells to spherical shape, we checked the expression of palladin and E-cadherin in HOXD8 expressing cells. Palladin (PALLD) is an actin-associated protein with 9 isoforms as showed by the Universal Protein Database. Several reports including our recent study [19] have revealed that palladin is associated with malignant characteristics of multiple malignancies including colorectal cancer. Here, we examined palladin expression in HOXD8 expressing cells. We generated either GFP or GFP HOXD8 expressing HCT116 and DLD-1 cells by retrovirus infection. As shown in Fig. 5A, immunoblot analysis showed that HOXD8 expression inhibited palladin isoforms (115 \& $140 \mathrm{kDa}$ ) in HCT116, however, DLD-1 cells did not show the expression of palladin. On the other hand, the epithelial cadherin (E-cadherin) has been implicated in tumor suppression and cellular adherence within a tissue, resulting in a decrease in cellular motility. In the current study, HOXD8 expression upregulated E-cadherin level in HCT116 and DLD-1 cells as compared to GFP only cells (Fig. 5A). As shown in Fig. 5B, we 
quantified these changes in the expression levels of palladin and E-cadherin by ImageJ analysis software. However, the phosphorylation of other signaling proteins, such as ERK1/2 and AKT, was not affected by HOXD8 expression (Figure 5A).

\subsection{TCGA indicates that HOXD8 is inversely correlated with STK38 and MYC}

To further dissect the tumor suppressing function of HOXD8, we performed The Cancer Genome Atlas (TCGA, Provisional) profiling of the genes significantly correlated with HOXD8 in human colorectal cancer patients' datasets. Among 30 genes positively correlated with HOXD8, ZNF618 (Zinc Finger Protein 618), FOXD4 (Forkhead Box D4), ETV5 (ETS Variant 5), LMCD1 (LIM And Cysteine Rich Domains 1) and ZDBF2 (Zinc Finger DBF-Type Containing 2) have been identified with transcription factor activity and sequence-specific DNA binding according to gene ontology (GO) annotations (Table 1). These structural homologs are sequencespecific transcription factors involved in developmental regulatory system to provide cells with specific positional identities on the anterior-posterior axis.

On the other hand, among 6 inversely correlated genes with HOXD8, STK38 (Serine/Threonine Kinase 38) and the well-known oncoprotein MYC have been identified by TCGA analysis (Table 2). Moreover, the dataset from TCGA database was analyzed to examine the correlation between HOXD8 and, STK38 and MYC at mRNA level in clinical colorectal cancer specimens by the cBioPortal platform. As shown in Fig. 6A and 6B, the correlation analysis in TCGA database showed that HOXD8 was inversely correlated with STK38 (Pearson:-0.31, Spearman: -0.39, $\mathrm{N}=382$ ) and MYC (Pearson: -0.124, Spearman: -0.144, N=382). However, a correlation analysis in TCGA dataset showed that STK38 was positively correlated with MYC (Pearson: 0.133, Spearman: 0.166, N=382) (Fig. 6C). To confirm the negative association between HOXD8 and MYC, we used qRT-PCR analysis to check the expression of MYC mRNA levels in either GFP or GFP HOXD8. As shown in Fig. 6D, exogenous expression of HOXD8 in HCT116, DLD-1 and HT29 cells downregulated MYC mRNA levels as compared to GFP only cells.

\subsection{Expression of HOXD8 augments apoptosis of colorectal cancer cells}

Serine-threonine kinase 38, STK38/NDR1 has been shown to be a potential "druggable" target in several pathologies in which autophagy is critically involved [32]. Moreover, depletion of STK38 suppresses growth of MYC-addicted tumors by decreasing MYC levels and increasing apoptosis, thus we checked the expression of apoptotic markers in HOXD8 expressing cells. As shown in Fig. 7A, HOXD8 expression upregulated the executioner caspases 6 and 7 in HCT116 
and DLD-1 cells. Also, expression of HOXD8 increased the apoptotic marker cleaved poly (ADPribose) polymerase (PARP) in both HCT116 and DLD-1 cells. We quantified the western blots using ImageJ analysis (Fig. 7B, 7C and 7D). Collectively, these findings clearly indicate the tumor suppressor function of HOXD8 via induction of apoptotic pathways in colorectal cancer cells.

\subsection{STRING database defines the functional interaction partners of HOXD8}

As an extension to the previous findings, we used the protein-protein interaction server, STRING, to define HOXD8 functional partners to further dissect its action in CRC. As shown in Supplementary Figure 2, among top three binding partners, prospero homeobox 1 (prospero homeobox 1) and homeobox D4 (HOXD4) were found to interact with HOXD8.

\section{Discussion}

In this report, we investigated the tumor suppressing role of HOXD8 in colorectal cancer cells by gain of function strategy given its lower expression in CRC. Ectopic expression of HOXD8 suppresses cancer cell proliferation, colony formation and cell invasiveness. We further elucidated STK38 kinase and MYC genes to be negatively associated with HOXD8. This negative association is proposed to be responsible for the induction of apoptotic events mediated by HOXD8 in cancer cells. HOXD8 has previously been linked to differentiation process, whereas retinoic acid-induced differentiation of neuroblastoma upregulates a number of HOX genes including HOXD8 [33]. Also, individual induction of HOXD8 in neuroblastoma cells is sufficient to downregulate cell cycle-promoting genes and upregulate neuronal differentiation genes. However, depletion of HOXD8 significantly inhibits the retinoic acid-induced differentiation [16].

Low expression of HOXD8 is reported in several malignancies including pediatric brain tumors [34] and colorectal cancer [1]. In the latter type, HOXD8 expression levels were significantly lower in hepatic metastatic tissues than those in primary tissue proposing a metastasis suppressor function of HOXD8. Given the physiological function of HOXD8 to give the cells positional information in adult, it is thought that loss of HOXD8 may give the cancer cells misinformation to recognize the liver as an orthotopic organ. Hence, disturbance of positional information may render the tumor cells adapted to different micro-environment. Paradoxically, other reports [35, 36] supported the overexpression of HOXD8 in non-small cell lung cancer to promote the cancer phenotype. Based on these findings, HOXD8 plays context-dependent functions in cancers given 
the nature of HOXD8 as a transcription factor targeting different downstream genes in each type of cancer.

Genome-wide methylation analysis in mantle cell lymphoma [37] and glioblastoma [38] revealed a significant aberrancy in promoter methylation patterns compared with normal cells. Among hypermethylated genes, HOXD8 had an aberrant methylation pattern associated with inverse changes in mRNA levels. In colorectal cancer, several pro-oncogenic miRNAs promote the oncogenic phenotype of colorectal cancer cells. miR-196a was reported to exert an oncogenic function in CRC by restricting the expression of HOXA7, HOXB8, HOXC8 and HOXD8 in a dose-dependent and gene-specific manner [17].

In the current study, the most significant reversely related genes with HOXD8 was the SerineThreonine Kinase 38, STK38, which is a member of the highly conserved NDR kinase in mammalian cells [39]. Changes in STK38 expression has been correlated with carcinogenesis. Some reports suggest that overexpression of STK38 is associated with breast ductal carcinoma [40] and melanoma [41] progression. Conversely, in gastric cancer and B-cell lymphoma, STK38 mRNA was downregulated as compared to normal tissues [42,43]. Hence, the role of STK38 in cancer progression appears to be context dependent. Bisikirska et al. [44] reported that knockdown of STK38 in vivo significantly suppresses B-cell lymphoma in a xenograft mouse model. It is thought that inactivation of STK38 activity reduces MYC protein expression and function, thus suppressing tumorigenesis mediated by MYC oncoprotein and increasing apoptosis. The oncogenic function of MYC is well-known in the etiology of most types of human cancers [45]. Overexpression of MYC oncoprotein elicits autonomous cell proliferation and fueling tumorigenesis [46]. Suppression of MYC activity is considered as a valuable therapeutic tool as inactivation of MYC would likely be associated with cytotoxicity given the physiological function of MYC in normal cells [44].

Apoptosis or programmed cell death (PCD) is a cellular suicide program required to eliminate superfluous cells for tissue morphogenesis and emerging harmful cells like in case of cancer [47,48]. Although apoptosis is tightly controlled in normal cells, it is disrupted in cancer to promote infinite cell growth. Also, its regulation on the transcriptional level is less studied and understood [44]. Homeobox genes like HOXD8 are homeodomain transcription factors that have pivotal roles in development by eliciting several developmental programs along the anteriorposterior axis. To this end, homeoproteins transcriptionally regulate cell-type specification, differentiation, proliferation and apoptosis in a highly coordinate manner. 
The interplay and regulatory wiring of differentiation and apoptosis are conserved in mammalian cells. For instance, CUT-like homeobox 1 (CUX1) activates the transcription of the proapoptotic gene puma [49] and has emerged as a tumor suppressor via interfering with PI3K signaling, a pathway known to control apoptosis [50]. Hence, it is very likely that the same regulatory interplay is used by homeobox transcription factors. This is because HOX genes are misregulated in cancer which is often associated with a deteriorated control of apoptotic pathways.

In summary, HOXD8 is a transcription factor with a tumor suppressing function in CRC. We propose its function to differentially shape tissues and control morphological outputs along the anterior-posterior axis by fine-tuning programmed cell death in healthy organisms. However, lower expression of this gene in CRC disrupts this homeostasis and inhibits apoptosis. Further investigations are required to uncover HOXD8 downstream genes and cofactors essential for target gene regulation and upstream regulators, which are often responsible for HOXD8 deregulation in various types of cancer.

\section{References}

(1) Kanai M, Hamada J, Takada M, et al. Aberrant expressions of HOX genes in colorectal and hepatocellular carcinomas. Oncol Rep. 2010;23(3):843-51.

(2) Levine M, Hoey T. Homeobox proteins as sequence-specific transcription factors. Cell. 1988;55(4):537-40.

(3) Ruddle FH, Bartels JL, Bentley KL, Kappen C, Murtha MT, Pendleton JW. Evolution of Hox genes. Annu Rev Genet. 1994;28:423-42.

(4) Mcginnis W, Krumlauf R. Homeobox genes and axial patterning. Cell. 1992;68(2):283-302.

(5) Rux DR, Wellik DM. Hox Genes in the Adult Skeleton: Novel Functions Beyond Embryonic Development. Dev Dyn. 2016;

(6) Alvarado-ruiz L, Martinez-silva MG, Torres-reyes LA, et al. HOXA9 is Underexpressed in Cervical Cancer Cells and its Restoration Decreases Proliferation, Migration and Expression of Epithelial-to-Mesenchymal Transition Genes. Asian Pac J Cancer Prev. 2016;17(3):1037-47.

(7) Morgan R, Simpson G, Gray S, et al. HOX transcription factors are potential targets and markers in malignant mesothelioma. BMC Cancer. 2016;16:85.

(8) Xia B, Shan M, Wang J, et al. Homeobox A11 hypermethylation indicates unfavorable prognosis in breast cancer. Oncotarget. 2016; 
(9) Yap LF, Lai SL, Patmanathan SN, et al. HOPX functions as a tumour suppressor in head and neck cancer. Sci Rep. 2016;6:38758.

(10) Joo MK, Park JJ, Chun HJ. Impact of homeobox genes in gastrointestinal cancer. World J Gastroenterol. 2016;22(37):8247-8256.

(11) Cantile M, Scognamiglio G, Marra L, et al. HOTAIR Role in Melanoma Progression and its Identification in the Blood of Patients with Advanced Disease. J Cell Physiol. 2017;

(12) Liu YJ, Zhu Y, Yuan HX, Zhang JP, Guo JM, Lin ZM. Overexpression of HOXC11 homeobox gene in clear cell renal cell carcinoma induces cellular proliferation and is associated with poor prognosis. Tumour Biol. 2015;36(4):2821-9.

(13) Olsen J, Eiholm S, Kirkeby LT, et al. CDX2 downregulation is associated with poor differentiation and MMR deficiency in colon cancer. Exp Mol Pathol. 2016;100(1):59-66.

(14) Hamid AR, Hoogland AM, Smit F, et al. The role of HOXC6 in prostate cancer development. Prostate. 2015;75(16):1868-76.

(15) Zhang L, Wan Y, Jiang Y, et al. Upregulation HOXA10 homeobox gene in endometrial cancer: role in cell cycle regulation. Med Oncol. 2014;31(7):52.

(16) Zha Y, Ding E, Yang L, et al. Functional dissection of HOXD cluster genes in regulation of neuroblastoma cell proliferation and differentiation. PLoS ONE. 2012;7(8):e40728.

(17) Schimanski CC, Frerichs K, Rahman F, et al. High miR-196a levels promote the oncogenic phenotype of colorectal cancer cells. World J Gastroenterol. 2009;15(17):2089-96.

(18) Asano E, Maeda M, Hasegawa H, et al. Role of palladin phosphorylation by extracellular signal-regulated kinase in cell migration. PLoS ONE. 2011;6(12):e29338.

(19) Mansour MA, Asano E, Hyodo T, et al. Special AT-rich sequence-binding protein 2 suppresses invadopodia formation in HCT116 cells via palladin inhibition. Exp Cell Res. 2015;332(1):78-88.

(20) Akter KA, Mansour MA, Hyodo T, Senga T. FAM98A associates with DDX1-C14orf166FAM98B in a novel complex involved in colorectal cancer progression. Int J Biochem Cell Biol. 2016;84:1-13.

(21) Mansour MA, Hyodo T, Akter KA, et al. SATB1 and SATB2 play opposing roles in c-Myc expression and progression of colorectal cancer. Oncotarget. 2016;7(4):4993-5006.

(22) Kurita, K., Maeda, M., Mansour, M. A., Kokuryo, T., Uehara, K., Yokoyama, Y., Nagino, M., Hamaguchi, M., Senga, T."TRIP13 is expressed in colorectal cancer and promotes cancer cell invasion". Oncology Letters 12.6 (2016): 5240-5246. 
(23) Akter KA, Mansour MA, Hyodo T, Ito S, Hamaguchi M, Senga T. FAM98A is a novel substrate of PRMT1 required for tumor cell migration, invasion, and colony formation. Tumour Biol. 2016;37(4):4531-9.

(24) Ayesha AK, Hyodo T, Asano E, et al. UBE2S is associated with malignant characteristics of breast cancer cells. Tumour Biol. 2016;37(1):763-72.

(25) Mansour MA, Hyodo T, Ito S, et al. SATB2 suppresses the progression of colorectal cancer cells via inactivation of MEK5/ERK5 signaling. FEBS J. 2015;282(8):1394-405.

(26) Albini A, Iwamoto Y, Kleinman HK, et al. A rapid in vitro assay for quantitating the invasive potential of tumor cells. Cancer Res. 1987;47(12):3239-45.

(27) Altschul SF, Madden TL, Schäffer AA, et al. Gapped BLAST and PSI-BLAST: a new generation of protein database search programs. Nucleic Acids Res. 1997;25(17):3389-402.

(28) Remmert M, Biegert A, Hauser A, Söding J. HHblits: lightning-fast iterative protein sequence searching by HMM-HMM alignment. Nat Methods. 2011;9(2):173-5.

(29) Biasini M, Bienert S, Waterhouse A, et al. SWISS-MODEL: modelling protein tertiary and quaternary structure using evolutionary information. Nucleic Acids Res. 2014;42(Web Server issue):W252-8.

(30) Arnold K, Bordoli L, Kopp J, Schwede T. The SWISS-MODEL workspace: a web-based environment for protein structure homology modelling. Bioinformatics. 2006;22(2):195-201.

(31) Benkert P, Biasini M, Schwede T. Toward the estimation of the absolute quality of individual protein structure models. Bioinformatics. 2011;27(3):343-50.

(32) Joffre C, Dupont N, Hoa L, et al. The Pro-apoptotic STK38 Kinase Is a New Beclin1 Partner Positively Regulating Autophagy. Curr Biol. 2015;25(19):2479-92.

(33) Manohar CF, Salwen HR, Furtado MR, Cohn SL. Up-regulation of HOXC6, HOXD1, and HOXD8 homeobox gene expression in human neuroblastoma cells following chemical induction of differentiation. Tumour Biol. 1996;17(1):34-47.

(34) Chakravadhanula M, Ozols VV, Hampton CN, Zhou L, Catchpoole D, Bhardwaj RD. Expression of the HOX genes and HOTAIR in atypical teratoid rhabdoid tumors and other pediatric brain tumors. Cancer Genet. 2014;207(9):425-8.

(35) Bao L, Zhang Y, Wang J, et al. Variations of chromosome 2 gene expressions among patients with lung cancer or non-cancer. Cell Biol Toxicol. 2016;32(5):419-35.

(36) Liu Y, Miao L, Ni R, et al. microRNA-520a-3p inhibits proliferation and cancer stem cell phenotype by targeting HOXD8 in non-small cell lung cancer. Oncol Rep. 2016;36(6):3529-3535. 
(37) Leshchenko VV, Kuo PY, Shaknovich R, et al. Genomewide DNA methylation analysis reveals novel targets for drug development in mantle cell lymphoma. Blood. 2010;116(7):102534.

(38) Shinawi T, Hill VK, Krex D, et al. DNA methylation profiles of long- and short-term glioblastoma survivors. Epigenetics. 2013;8(2):149-56.

(39) Hergovich A, Schmitz D, Hemmings BA. The human tumour suppressor LATS1 is activated by human MOB1 at the membrane. Biochem Biophys Res Commun. 2006;345(1):50-8.

(40) Adeyinka A, Emberley E, Niu Y, et al. Analysis of gene expression in ductal carcinoma in situ of the breast. Clin Cancer Res. 2002;8(12):3788-95.

(41) Millward TA, Heizmann CW, Schäfer BW, Hemmings BA. Calcium regulation of Ndr protein kinase mediated by S100 calcium-binding proteins. EMBO J. 1998;17(20):5913-22.

(42) Cui DX, Zhang L, Yan XJ, et al. A microarray-based gastric carcinoma prewarning system. World J Gastroenterol. 2005;11(9):1273-82.

(43) Basso K, Margolin AA, Stolovitzky G, Klein U, Dalla-favera R, Califano A. Reverse engineering of regulatory networks in human B cells. Nat Genet. 2005;37(4):382-90.

(44) Bisikirska BC, Adam SJ, Alvarez MJ, et al. STK38 is a critical upstream regulator of MYC's oncogenic activity in human B-cell lymphoma. Oncogene. 2013;32(45):5283-91.

(45) Marcu KB, Bossone SA, Patel AJ. myc function and regulation. Annu Rev Biochem. 1992;61:809-60.

(46) Bouchard C, Staller P, Eilers M. Control of cell proliferation by Myc. Trends Cell Biol. 1998;8(5):202-6.

(47) Fuchs Y, Steller H. Programmed cell death in animal development and disease. Cell. $2011 ; 147(4): 742-58$.

(48) Suzanne M, Steller H. Shaping organisms with apoptosis. Cell Death Differ. 2013;20(5):669-75.

(49) Zhai Z, Ha N, Papagiannouli F, et al. Antagonistic regulation of apoptosis and differentiation by the Cut transcription factor represents a tumor-suppressing mechanism in Drosophila. PLoS Genet. 2012;8(3):e1002582.

(50) Costa BM, Smith JS, Chen Y, et al. Reversing HOXA9 oncogene activation by PI3K inhibition: epigenetic mechanism and prognostic significance in human glioblastoma. Cancer Res. 2010;70(2):453-62.

\section{Figure Legends}


Figure 1. HOXD8 is downregulated in clinical colorectal cancer tissues and HOXD8 expression reduces cancer cell proliferation. (A) The level of HOXD8 mRNA in colorectal cancer ( $\mathrm{n}=18$ ) and normal colorectal $(n=3)$ tissues was evaluated by quantitative RT-PCR. The graph indicates the relative HOXD8 mRNA levels. (B) Analysis of the Oncomine colorectal adenocarcinoma database (https://www.oncomine.org) using colorectal cancer vs. normal colon datasets showing the relative expression of HOXD8 mRNA in clinical colorectal cancer specimens as compared to the normal colon. (C) The relative mRNA expression of HOXD8 normalized to glyceraldehydes3-phosphate dehydrogenase (GAPDH) mRNA in different colorectal cancer cell lines was examined by qRT-PCR analysis. (D) HCT116 and DLD-1 cells constitutively expressing GFP or GFP HOXD8 were established by retrovirus infection. The expression of the indicated proteins (GFP, B-actin) in the cell lines was examined by immunoblotting. (E) HCT116, DLD-1 and HT29 cells were infected with either GFP or GFP HOXD8 vector by retroviral infection. The number of viable cells at the indicated time points was determined using a Cell Counting Kit-8 assay.

Figure 2. HOXD8 reduces the colony forming capacity of several colorectal cancer cells. (A) HCT116 cells expressing either GFP or GFP HOXD8 were subjected to a colony formation assay. Representative images are shown, and the graphs indicate the average number (mean $\pm \mathrm{SE}$ ) and size (mean $\pm \mathrm{SE}$ ) of colonies per field $(* \mathrm{P}<0.05)$. (B) DLD-1 cells expressing either GFP or GFP HOXD8 were subjected to a colony formation assay. Representative images are shown, and the graphs indicate the average number (mean $\pm \mathrm{SE}$ ) and size (mean $\pm \mathrm{SE}$ ) of colonies per field (*P < 0.05). (C) HT29 cells expressing either GFP or GFP HOXD8 were subjected to a colony formation assay. Representative images are shown, and the graphs indicate the average number $($ mean $\pm \mathrm{SE})$ and size (mean $\pm \mathrm{SE})$ of colonies per field $(* \mathrm{P}<0.05)$.

Figure 3. HOXD8 inhibits colorectal cancer cells invasion. (A) Representative images of the cell morphology and fluorescence (GFP) of HCT116, DLD-1 and HT29 cells expressing either GFP or GFP HOXD8; scale bar $=50 \mu \mathrm{m}$. The arrows show the apoptotic cells formed upon expression of HOXD8 (B) GFP or GFP-SATB2 DLD-1 cells were subjected to a Boyden chamber invasion assay. Representative images of invaded DLD-1 cells are shown, and the graph indicates the average number (mean $\pm \mathrm{SE})$ of invaded cells per field $(* \mathrm{P}<0.05)$.

Figure 4. Homology modeling and oligomeric state conservation of HOXD8. (A) Homology modeling analysis results indicating 2r5z.1.c as the most proper template for HOXD8 with 65.79 
sequence identity. (B) Model-template alignment by server Swiss-model. (C) The ribbon style of HOXD8 protein is shown with coil, helix and strand. (D) Hydrophobicity surface of HOXD8 protein is shown with colors ranging from dodger blue for the most hydrophilic to white at 0.0 to orange red for the most hydrophobic.

Figure 5. Expression of HOXD8 inhibits palladin (140 kDa) and upregulates E-cadherin in colorectal cancer cells. (A) HCT116 and DLD-1 cells constitutively expressing GFP or GFP HOXD8 were established by retrovirus infection and the expression of palladin and E-cadherin was checked by immunoblotting. B-actin was used as loading control for the western blot analysis. Arrows indicate the several isoforms of palladin (200, 140, 115, 90 \& $50 \mathrm{kDa}$ ) (B) ImageJ analysis was used to quantify the signal intensities of western blots of palladin and Ecadherin taking 8 -actin as the control protein.

Figure 6. HOXD8 is negatively associated with STK38 and MYC genes. (A) Analysis of The Cancer Genome Atlas (TCGA) colorectal adenocarcinoma database (TCGA, Provisional) using cBioPortal showing the correlation between HOXD8 and STK38 mRNA levels. (B) The correlation analysis performed by TCGA to compare between HOXD8 and MYC mRNA levels. (C) The correlation analysis performed by TCGA to compare between STK38 and MYC mRNA levels. (D) The MYC mRNA expression level in HCT116, DLD-1 and HT29 cells either expressing GFP or GFP HOXD8 was analyzed by quantitative RT-PCR analysis. The graph indicates relative MYC mRNA level as normalized to GAPDH.

Figure 7. Expression of HOXD8 increases executive caspases $6 \& 7$ and cleaved-PARP. (A) HCT116 and DLD-1 cells constitutively expressing GFP or GFP HOXD8 were established by retrovirus infection. The expression of the indicated proteins (cleaved caspase 6, cleaved caspase 7 and cleaved PARP) in the cell lines was examined by immunoblotting taking 8-actin as the loading control. (B) ImageJ analysis was used to quantify the signal intensities of western blots of cleaved caspase 6 taking B-actin as the control protein. (C) ImageJ analysis was used to quantify the signal intensities of western blots of cleaved caspase 7 taking B-actin as the control 
protein. (D) ImageJ analysis was used to quantify the signal intensities of western blots of cleaved PARP taking B-actin as the control protein.

Supplementary Figure 1. Expression of HOXD8 increases percentage of apoptotic cells. (A) Bar graph of the TUNEL-positive apoptotic cells in FLAG or FLAG HOXD8 cells. HCT116, DLD-1 and HT29 cells constitutively expressing FLAG or FLAG HOXD8 were established by retrovirus infection. The percentage of apoptotic cells were assessed by the terminal deoxynucleotidyl transferase-mediated dUTP biotin nick-end labeling (TUNEL) assay using the In Situ Cell Death Detection.

Supplementary Figure 2. Binding partners of HOXD8 as analyzed by STRING database. (A) The network nodes represent proteins that are found to interact with HOXD8. (B) The interacting proteins were tabulated with its respective gene name and score of interaction as predicted by STRING database. 
Figure 1

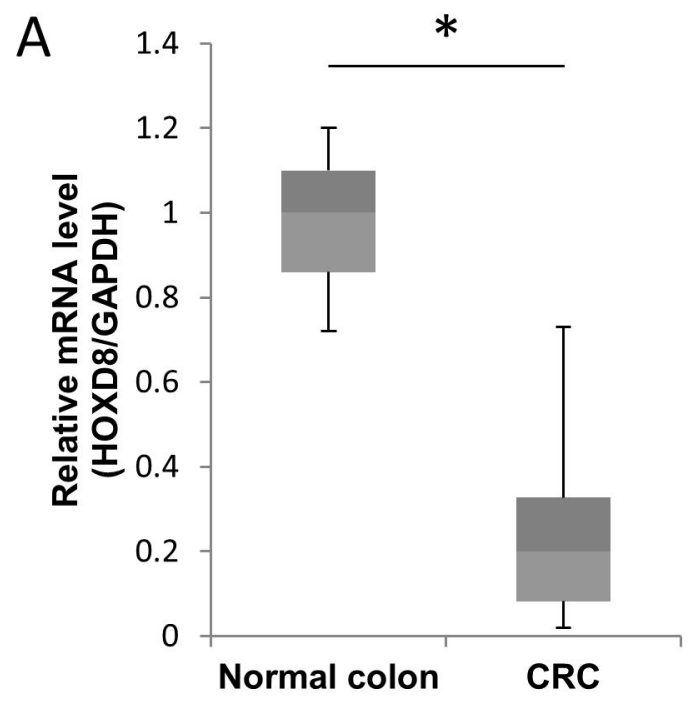

B

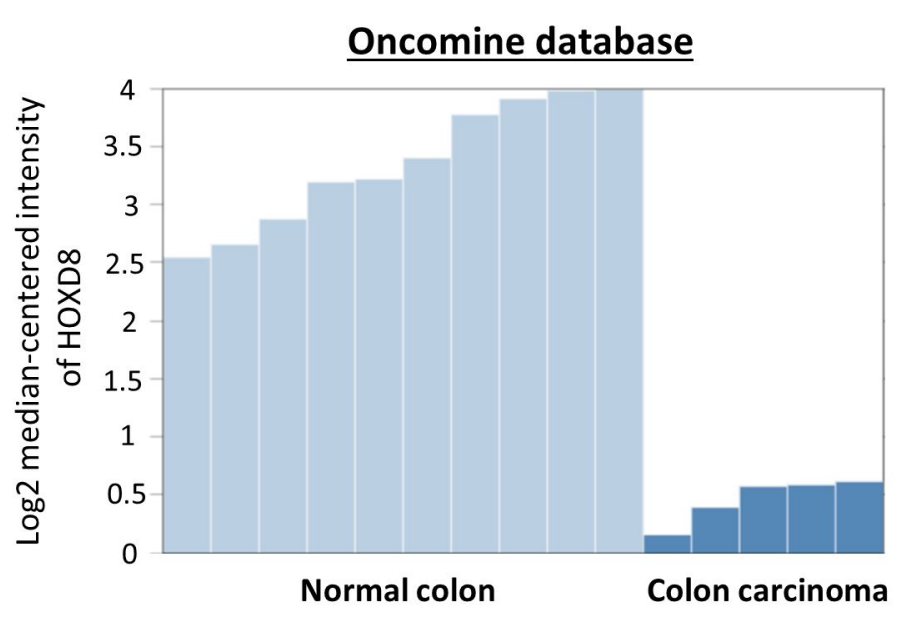

C

D

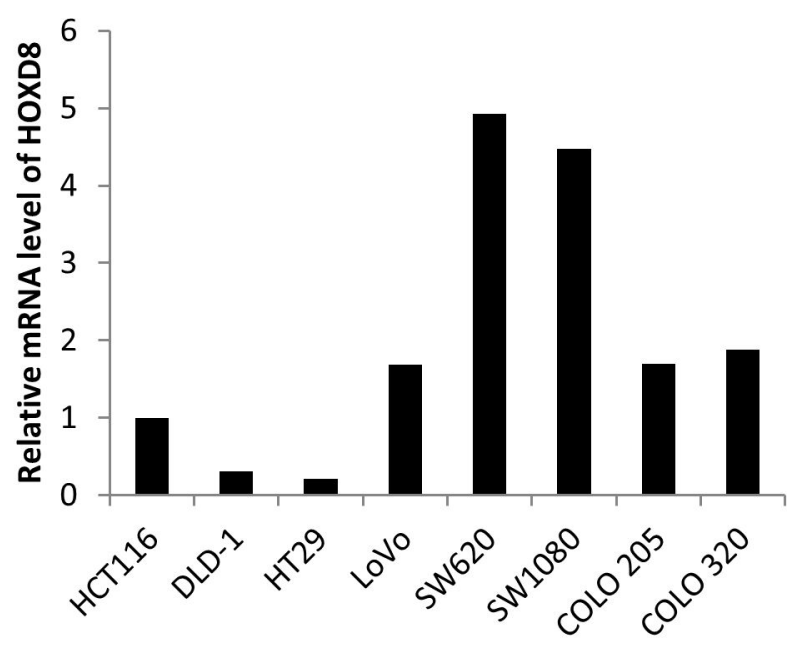

E

Colorectal cancer cell lines
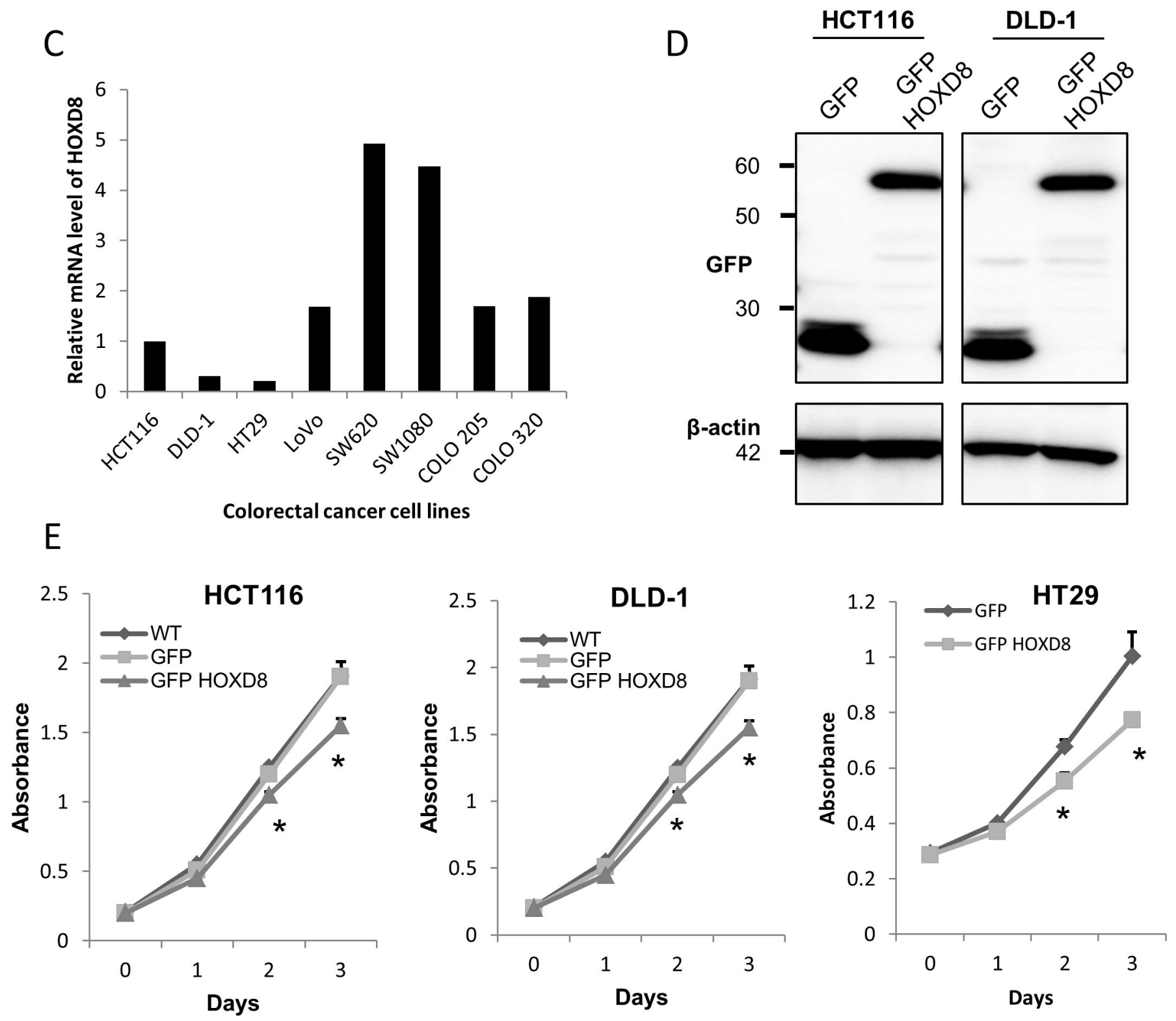
Figure 2
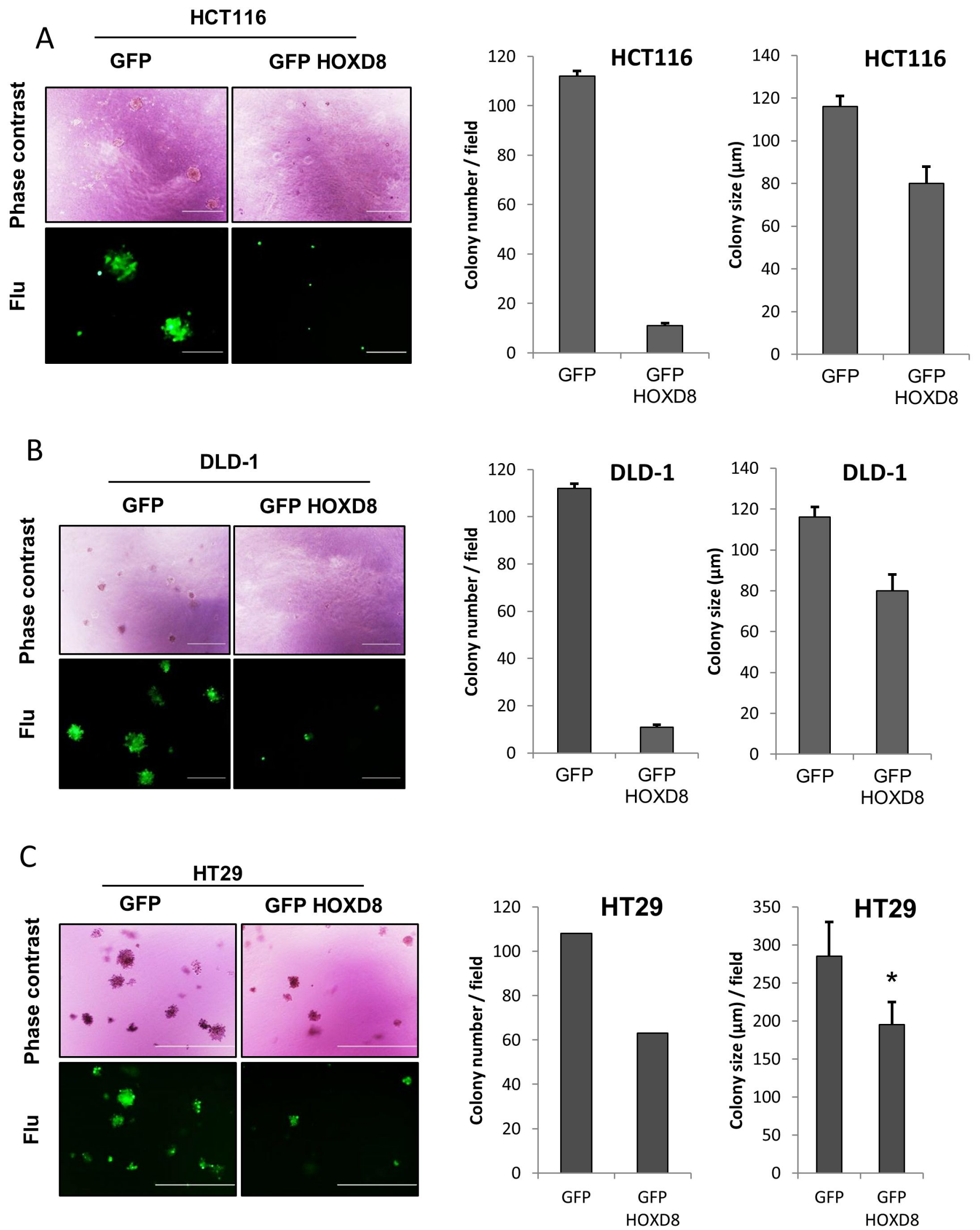
Figure 3
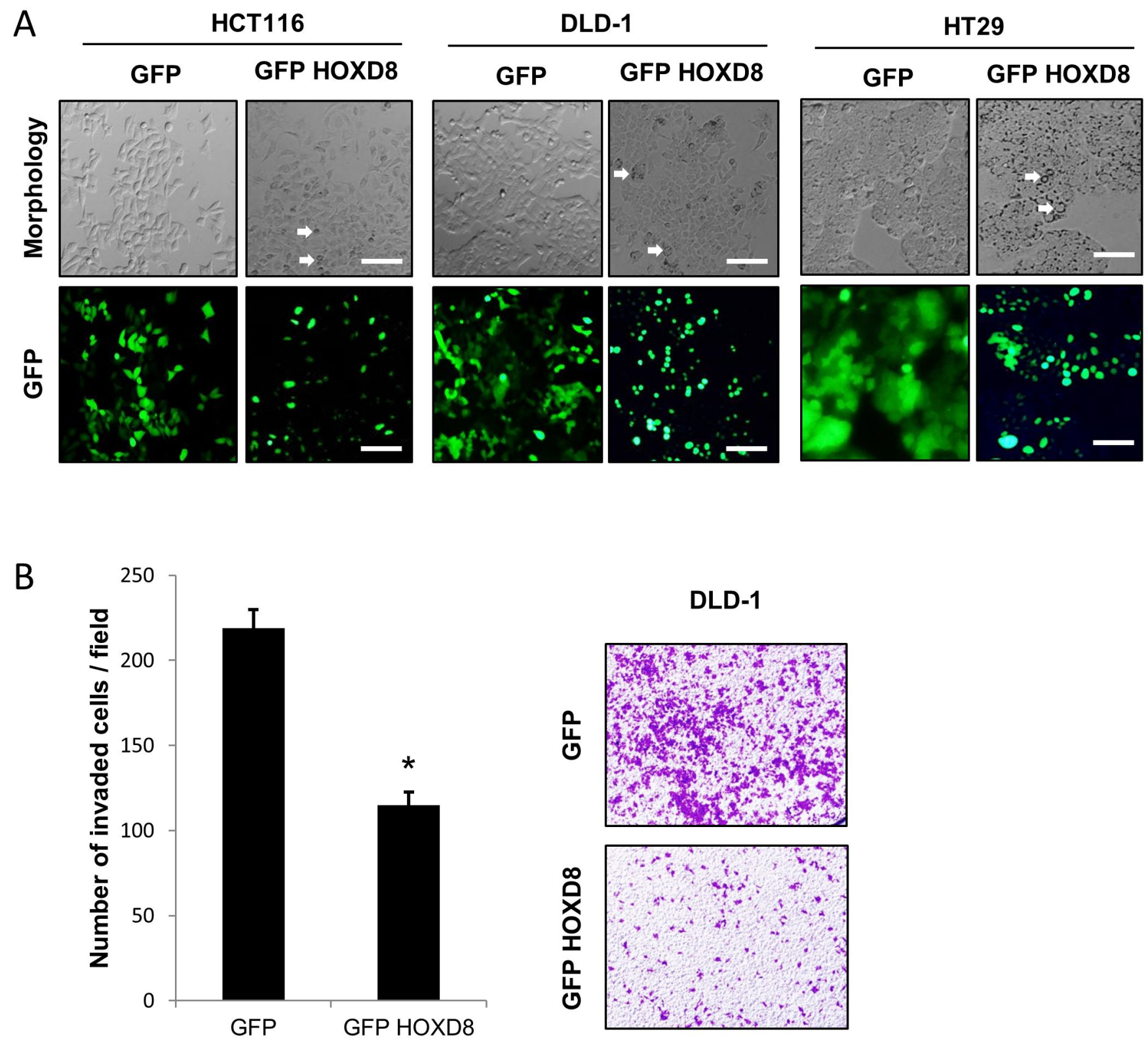


\section{Figure 4}

A

\begin{tabular}{|c|c|c|c|c|c|c|}
\hline Model \#01 & File & Built with & Oligo-State & Ligands & GMQE & QMEAN \\
\hline 3 & PDB & ProMod3 Version 1.0.2. & MONOMER & None & 0.17 & -1.17 \\
\hline
\end{tabular}

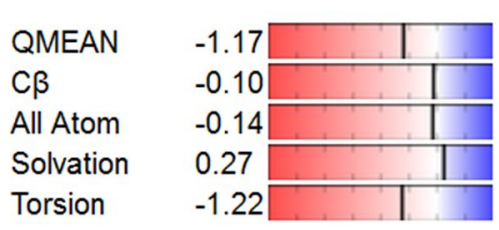

\begin{tabular}{|c|c|c|}
\hline Template & $\begin{array}{c}\text { Seq } \\
\text { Identity }\end{array}$ & \begin{tabular}{c} 
Oligo-state \\
\hline 2 r5z.1.C
\end{tabular} \\
\hline & 65.79 & $\begin{array}{c}\text { hetero- } \\
\text { oligomer }\end{array}$ \\
\hline
\end{tabular}

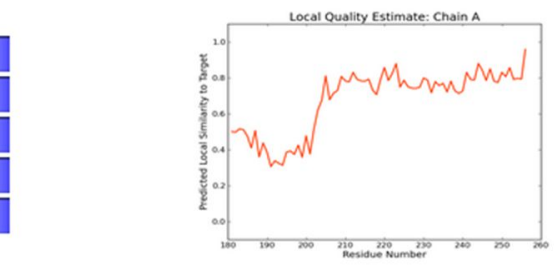
Found Method Resolution Seq by Method Resolution Similarity

\begin{tabular}{|l|l|l|l|}
\hline BLAST & $X$-ray & $2.60 \AA$ & 0.51 \\
\hline
\end{tabular}

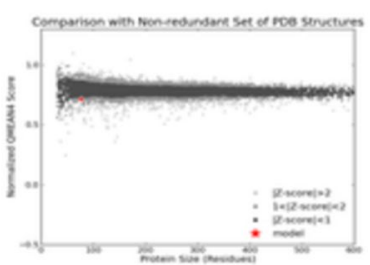

Range Coverage Description

0.26
Homeotic protein Sex combs reduced

The template contained no ligands.

B

\section{Model-Template Alignment}

Mode1_01 MSSYEVNPLYSKYKAAAAAAAAAGBANPTYYDCHEAPEVGGRHAAAAALQLYGNSAAGEPHAPPQAHAHPHPS 75

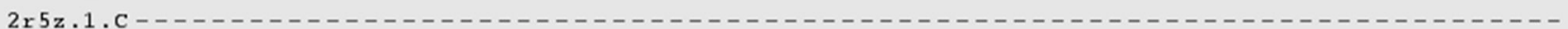

Model_01 PPPSGTGCGGRGRGQBYEHPGGGSPAAYQAAPPPPHPPPPPPPPPCGGIACHGEPAKEYG DNLQRQPIETT 150

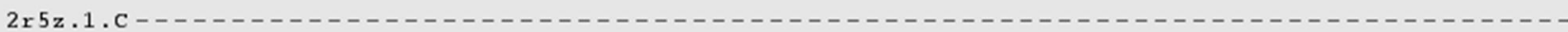

Model_01 QQBABLVQYPDCKSSS GNI GEDPDHLNQS S S SQMEPWMRPQAAPG-

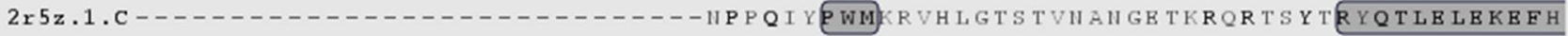

Model_01 FNPYLTRKRRIEVSHALALTERQVKIWFQNRRMKWKKENWKDKEPVSRQBVKDGBTKKBAQBLBBDRABGLTN 290 2 r5z.1.CENR YLTRRRRIBI AHALSLT ERQIKIWEQNRRMKWKKBH

C

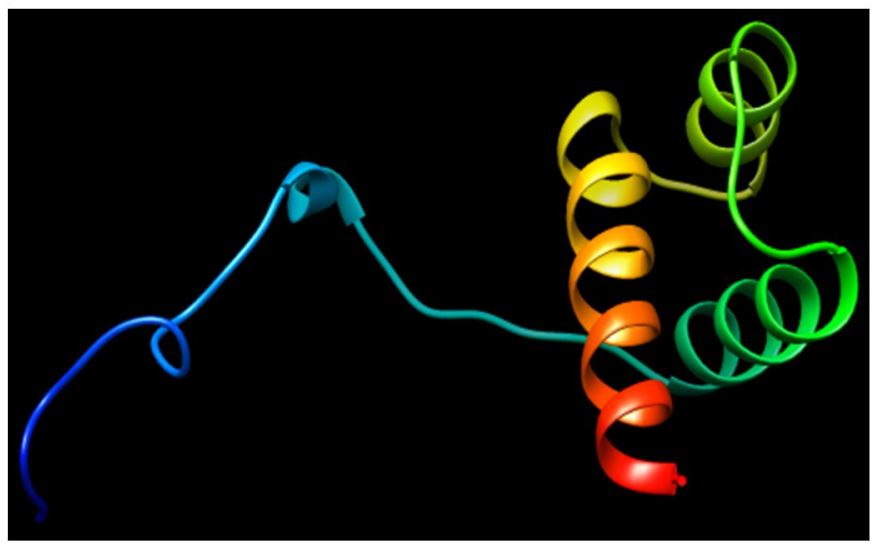

D

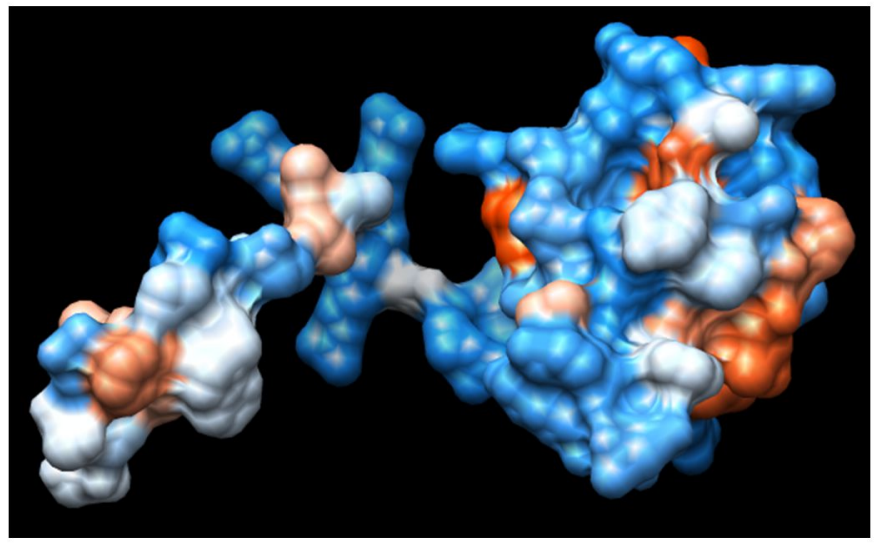


Figure 5

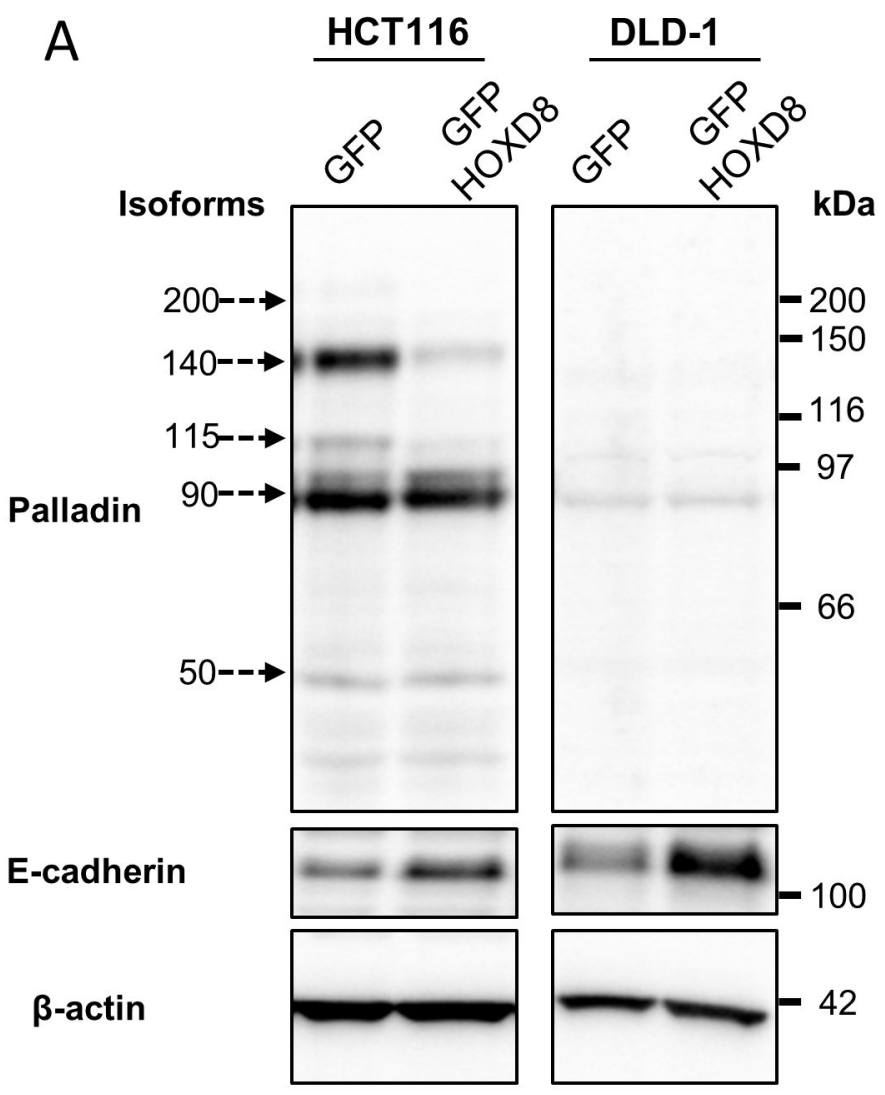

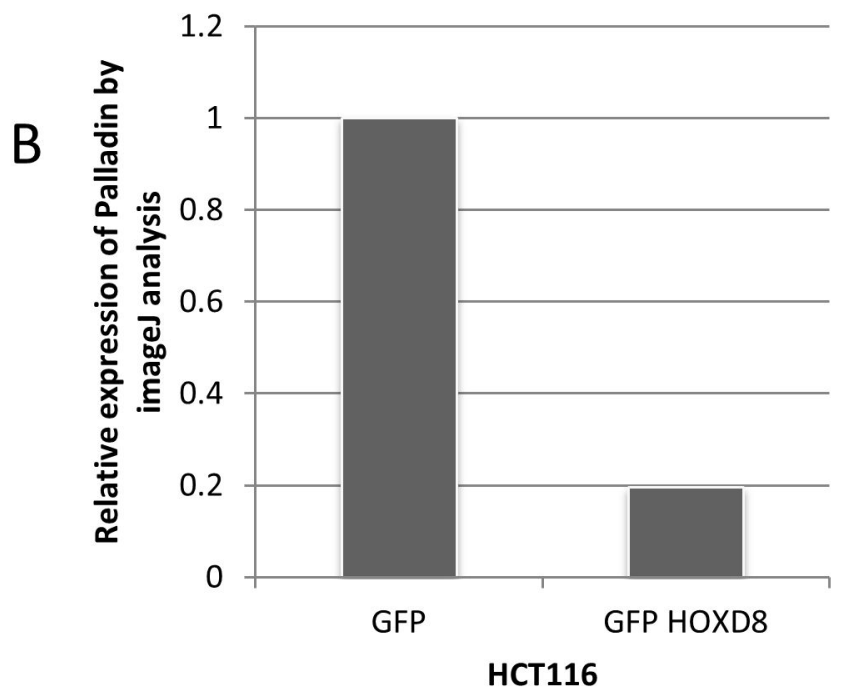

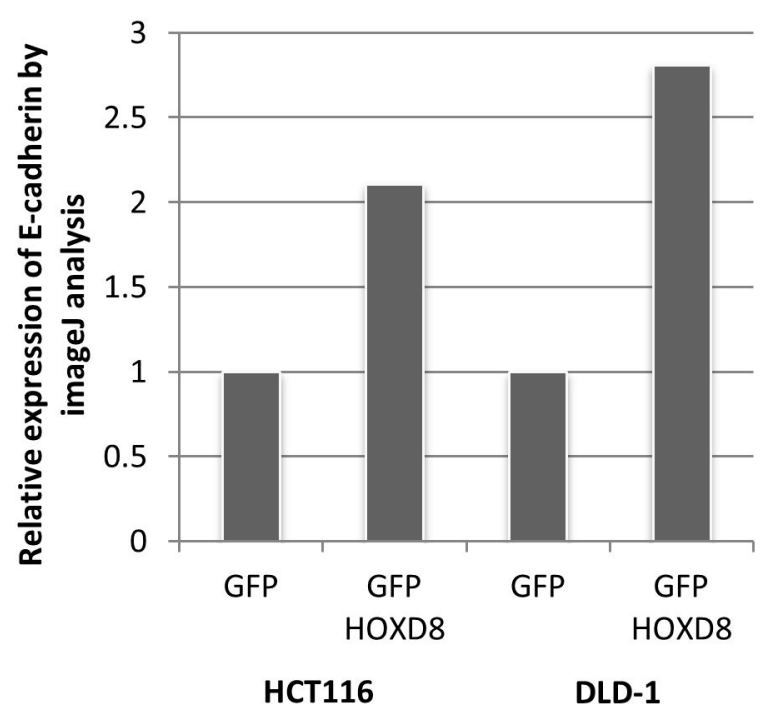


A

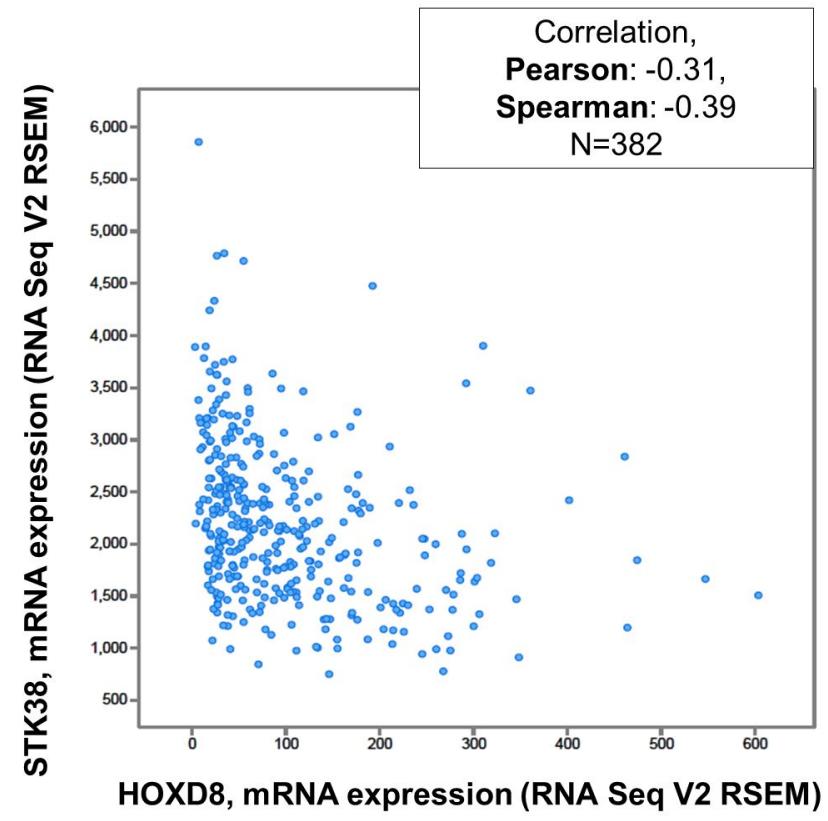

B

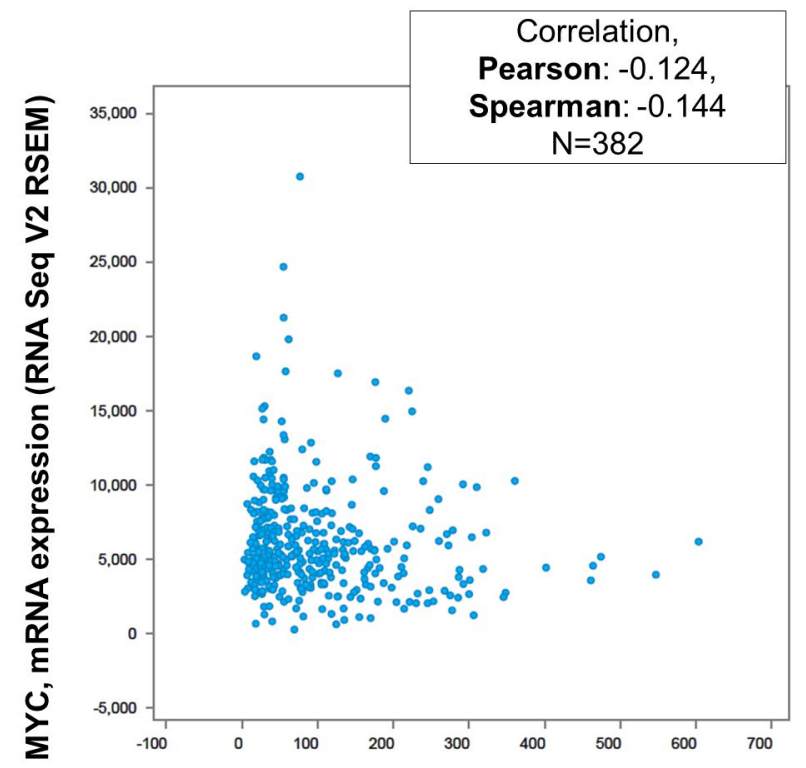

HOXD8, mRNA expression (RNA Seq V2 RSEM)

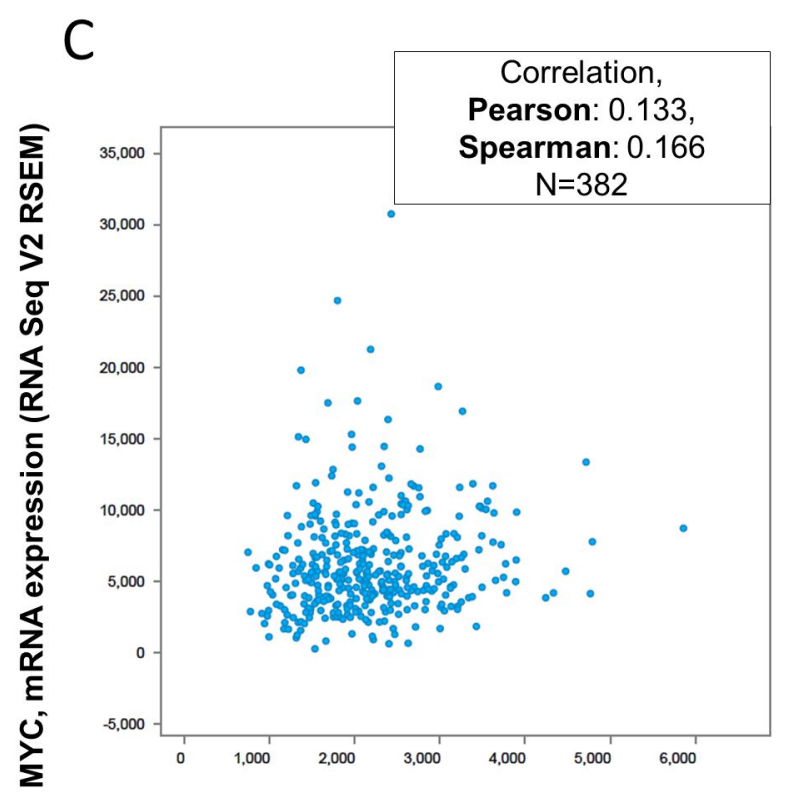

STK38, mRNA expression (RNA Seq V2 RSEM)
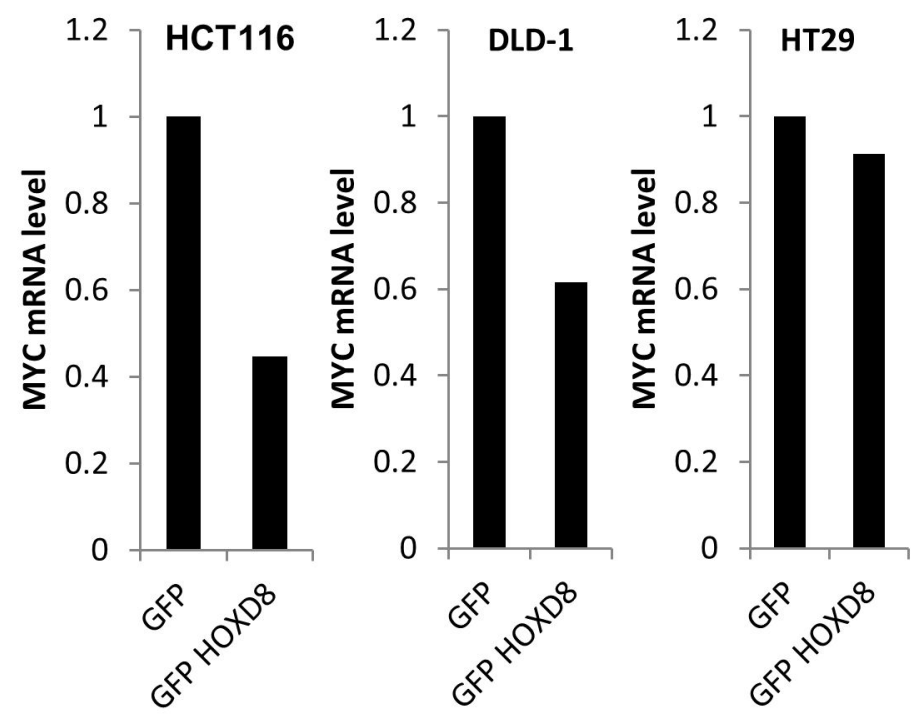
Figure 7

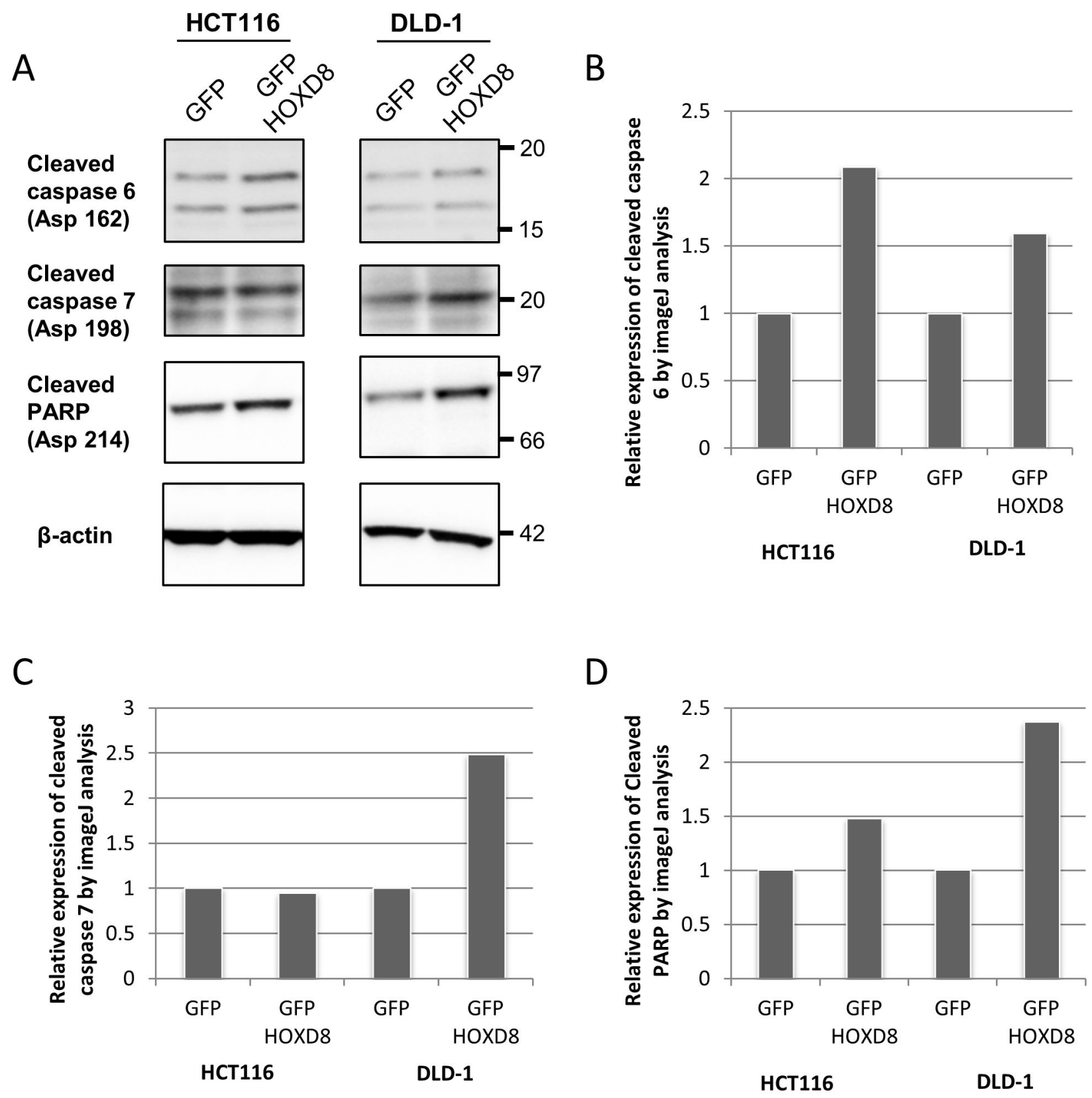


Table 1: Genetic profiling of the most significant positively correlated genes with HOXD8 performed by The Cancer Genome Atlas (TCGA, Provisional).

\begin{tabular}{|c|c|c|c|c|}
\hline Correlated gene & $\begin{array}{l}\text { Pearson's } \\
\text { Correlation } \\
\end{array}$ & $\begin{array}{l}\text { Spearman's } \\
\text { Correlation }\end{array}$ & Entrez Gene & GeneCards \\
\hline $\begin{array}{l}\text { ZNF618 (Zinc } \\
\text { Finger Protein } \\
\text { 618) }\end{array}$ & 0.33 & 0.43 & Not available & $\begin{array}{l}\text { GO annotations connected } \\
\text { to this gene: nucleic acid } \\
\text { binding. }\end{array}$ \\
\hline $\begin{array}{l}\text { FOXD4 } \\
\text { (Forkhead Box } \\
\text { D4) }\end{array}$ & 0.35 & 0.32 & $\begin{array}{l}\text { The gene plays } \\
\text { crucial roles in the } \\
\text { regulation of } \\
\text { metabolism, cell } \\
\text { proliferation and } \\
\text { gene expression. }\end{array}$ & $\begin{array}{l}\text { GO annotations connected } \\
\text { to this gene: transcription } \\
\text { factor activity, sequence- } \\
\text { specific DNA binding and } \\
R N A \text { polymerase II } \\
\text { transcription factor } \\
\text { activity. }\end{array}$ \\
\hline $\begin{array}{l}\text { MTMR9 } \\
\text { (Myotubularin } \\
\text { Related Protein } \\
\text { 9) } \\
\end{array}$ & 0.32 & 0.37 & $\begin{array}{l}\text { The encoded protein } \\
\text { is thought to have a } \\
\text { role in the control of } \\
\text { cell proliferation. }\end{array}$ & $\begin{array}{l}\text { GO annotations connected } \\
\text { to this gene: phosphatase } \\
\text { activity and enzyme } \\
\text { regulator activity. }\end{array}$ \\
\hline $\begin{array}{l}\text { RAET1K } \\
\text { (Retinoic Acid } \\
\text { Early Transcript } \\
\text { 1K Pseudogene) }\end{array}$ & 0.33 & 0.34 & Not available & Pseudogene \\
\hline $\begin{array}{l}\text { FYN (FYN Proto- } \\
\text { Oncogene, Src } \\
\text { Family Tyrosine } \\
\text { Kinase) }\end{array}$ & 0.31 & 0.39 & $\begin{array}{l}\text { It is implicated in } \\
\text { the control of cell } \\
\text { growth. }\end{array}$ & $\begin{array}{l}\text { GO annotations connected } \\
\text { to this gene: transferase } \\
\text { activity, transferring } \\
\text { phosphorus-containing } \\
\text { groups and protein } \\
\text { tyrosine kinase activity. }\end{array}$ \\
\hline $\begin{array}{l}\text { DBN1 (Drebrin } \\
\text { 1) }\end{array}$ & 0.35 & 0.39 & $\begin{array}{l}\text { The encoded protein } \\
\text { is a cytoplasmic } \\
\text { actin-binding } \\
\text { protein. }\end{array}$ & $\begin{array}{l}\text { GO annotations connected } \\
\text { to this gene: actin binding } \\
\text { and profilin binding. }\end{array}$ \\
\hline $\begin{array}{l}\text { TXNDC15 } \\
\text { (Thioredoxin } \\
\text { Domain } \\
\text { Containing 15) }\end{array}$ & 0.34 & 0.39 & Not available & Protein Coding gene. \\
\hline $\begin{array}{l}\text { C5orf15 } \\
\text { (Chromosome } 5 \\
\text { Open Reading } \\
\text { Frame 15) } \\
\end{array}$ & 0.35 & 0.36 & Not available & Protein Coding gene. \\
\hline $\begin{array}{l}\text { SGTB (Small } \\
\text { Glutamine Rich } \\
\text { Tetratricopeptide } \\
\text { Repeat } \\
\text { Containing Beta) }\end{array}$ & 0.38 & 0.38 & Not available & Protein Coding gene. \\
\hline $\begin{array}{l}\text { SPRY1 (Sprouty } \\
\text { RTK Signaling } \\
\text { Antagonist 1) }\end{array}$ & 0.31 & 0.34 & Not available & Protein Coding gene. \\
\hline $\begin{array}{l}\text { ANXA5 (Annexin } \\
\text { A5) }\end{array}$ & 0.34 & 0.40 & $\begin{array}{l}\text { It is a phospholipase } \\
\text { A2 and protein }\end{array}$ & $\begin{array}{l}\text { GO annotations connected } \\
\text { to this gene: calcium ion }\end{array}$ \\
\hline
\end{tabular}




\begin{tabular}{|c|c|c|c|c|}
\hline & & & $\begin{array}{l}\text { kinase C inhibitory } \\
\text { protein. }\end{array}$ & $\begin{array}{l}\text { binding and calcium- } \\
\text { dependent phospholipid } \\
\text { binding. }\end{array}$ \\
\hline $\begin{array}{l}\text { ETV5 (ETS } \\
\text { Variant 5) }\end{array}$ & 0.39 & 0.40 & Not available & $\begin{array}{l}\text { GO annotations connected } \\
\text { to this gene: transcription } \\
\text { factor activity and } \\
\text { sequence-specific DNA } \\
\text { binding. }\end{array}$ \\
\hline $\begin{array}{l}\text { USP13 } \\
\text { (Ubiquitin } \\
\text { Specific } \\
\text { Peptidase 13 } \\
\text { (Isopeptidase T- } \\
\text { 3)) }\end{array}$ & 0.30 & 0.31 & Not available & $\begin{array}{l}\text { Among its related } \\
\text { pathways are Ubiquitin- } \\
\text { Proteasome Dependent } \\
\text { Proteolysis. }\end{array}$ \\
\hline $\begin{array}{l}\text { WWTR1 (WW } \\
\text { Domain } \\
\text { Containing } \\
\text { Transcription } \\
\text { Regulator 1) }\end{array}$ & 0.33 & 0.42 & Not available & $\begin{array}{l}\text { GO annotations connected } \\
\text { to this gene: protein } \\
\text { homodimerization activity } \\
\text { and transcription } \\
\text { corepressor activity. }\end{array}$ \\
\hline $\begin{array}{l}\text { LMCD1 (LIM } \\
\text { And Cysteine } \\
\text { Rich Domains 1) }\end{array}$ & 0.37 & 0.46 & $\begin{array}{l}\text { The encoded protein } \\
\text { may act as a co- } \\
\text { regulator of } \\
\text { transcription. }\end{array}$ & $\begin{array}{l}\text { GO annotations connected } \\
\text { to this gene: transcription } \\
\text { corepressor activity. }\end{array}$ \\
\hline $\begin{array}{l}\text { GNAI2 (G } \\
\text { Protein Subunit } \\
\text { Alpha I2) }\end{array}$ & 0.35 & 0.44 & $\begin{array}{l}\text { It is involved in the } \\
\text { hormonal regulation } \\
\text { of adenylate cyclase. }\end{array}$ & $\begin{array}{l}\text { GO annotations connected } \\
\text { to this gene: GTP binding } \\
\text { and signal transducer } \\
\text { activity. }\end{array}$ \\
\hline $\begin{array}{l}\text { ZDBF2 (Zinc } \\
\text { Finger DBF-Type } \\
\text { Containing 2) }\end{array}$ & 0.33 & 0.34 & $\begin{array}{l}\text { The encoded protein } \\
\text { contains DBF4-type } \\
\text { zinc finger domains. }\end{array}$ & $\begin{array}{l}\text { GO annotations connected } \\
\text { to this gene: nucleic acid } \\
\text { binding. }\end{array}$ \\
\hline $\begin{array}{l}\text { CHN1 (Chimerin } \\
\text { 1) }\end{array}$ & 0.32 & 0.40 & $\begin{array}{l}\text { It plays an } \\
\text { important role in } \\
\text { neuronal signal- } \\
\text { transduction }\end{array}$ & $\begin{array}{l}\text { GO annotations connected } \\
\text { to this gene: GTPase } \\
\text { activator activity and } \\
\text { ephrin receptor binding. }\end{array}$ \\
\hline $\begin{array}{l}\text { HOXD1 } \\
\text { (Homeobox D1) }\end{array}$ & 0.41 & 0.55 & $\begin{array}{l}\text { Transcription factor } \\
\text { involved in } \\
\text { differentiation and } \\
\text { limb development. }\end{array}$ & $\begin{array}{l}\text { GO annotations connected } \\
\text { to this gene: sequence- } \\
\text { specific DNA binding. }\end{array}$ \\
\hline $\begin{array}{l}\text { HOXD3 } \\
\text { (Homeobox D3) }\end{array}$ & 0.71 & 0.72 & $\begin{array}{l}\text { It is a transcription } \\
\text { factor that plays an } \\
\text { important role in } \\
\text { morphogenesis in all } \\
\text { multicellular } \\
\text { organisms. }\end{array}$ & $\begin{array}{l}\text { GO annotations connected } \\
\text { to this gene: transcription } \\
\text { factor activity and } \\
\text { sequence-specific DNA } \\
\text { binding. }\end{array}$ \\
\hline $\begin{array}{l}\text { HOXD4 } \\
\text { (Homeobox D4) }\end{array}$ & 0.69 & 0.74 & $\begin{array}{l}\text { It plays an } \\
\text { important role in } \\
\text { morphogenesis in all } \\
\text { multicellular } \\
\text { organisms. }\end{array}$ & $\begin{array}{l}\text { GO annotations connected } \\
\text { to this gene: transcription } \\
\text { factor activity and } \\
\text { sequence-specific DNA } \\
\text { binding. }\end{array}$ \\
\hline $\begin{array}{l}\text { HOXD9 } \\
\text { (Homeobox D9) }\end{array}$ & 0.63 & 0.71 & $\begin{array}{l}\text { It plays an } \\
\text { important role in } \\
\text { morphogenesis in all } \\
\text { multicellular } \\
\text { organisms. }\end{array}$ & $\begin{array}{l}\text { GO annotations connected } \\
\text { to this gene: transcription } \\
\text { factor activity, sequence- } \\
\text { specific DNA binding and } \\
R N A \text { polymerase II }\end{array}$ \\
\hline
\end{tabular}




\begin{tabular}{|c|c|c|c|c|}
\hline & & & & $\begin{array}{l}\text { regulatory region } \\
\text { sequence-specific DNA } \\
\text { binding. }\end{array}$ \\
\hline $\begin{array}{l}\text { HOXD10 } \\
\text { (Homeobox D10) }\end{array}$ & 0.48 & 0.41 & $\begin{array}{l}\text { The encoded protein } \\
\text { contains a homeobox } \\
\text { DNA-binding } \\
\text { domain. }\end{array}$ & $\begin{array}{l}\text { It is related to } \\
\text { Proteoglycans in cancer } \\
\text { and MicroRNAs in cancer. } \\
\text { GO annotations connected } \\
\text { to this gene: transcription } \\
\text { factor activity, sequence- } \\
\text { specific DNA binding and } \\
\text { chromatin binding. }\end{array}$ \\
\hline $\begin{array}{l}\text { HOXD11 } \\
\text { (Homeobox D11) }\end{array}$ & 0.50 & 0.42 & $\begin{array}{l}\text { It plays an } \\
\text { important role in } \\
\text { morphogenesis in all } \\
\text { multicellular } \\
\text { organisms. }\end{array}$ & $\begin{array}{l}\text { GO annotations connected } \\
\text { to this gene: sequence- } \\
\text { specific DNA binding. }\end{array}$ \\
\hline $\begin{array}{l}\text { HOXD13 } \\
\text { (Homeobox D13) }\end{array}$ & 0.42 & 0.35 & $\begin{array}{l}\text { It plays an } \\
\text { important role in } \\
\text { morphogenesis in all } \\
\text { multicellular } \\
\text { organisms. } \\
\end{array}$ & $\begin{array}{l}\text { GO annotations connected } \\
\text { to this gene: transcription } \\
\text { factor activity, sequence- } \\
\text { specific DNA binding and } \\
\text { chromatin binding. }\end{array}$ \\
\hline $\begin{array}{l}\text { GPR155 (G } \\
\text { Protein-Coupled } \\
\text { Receptor 155) }\end{array}$ & 0.39 & 0.32 & Not available & Protein Coding gene. \\
\hline $\begin{array}{l}\text { MAP4K4 } \\
\text { (Mitogen- } \\
\text { Activated Protein } \\
\text { Kinase Kinase } \\
\text { Kinase Kinase 4) }\end{array}$ & 0.31 & 0.30 & $\begin{array}{l}\text { It is a member of the } \\
\text { serine/threonine } \\
\text { protein kinase } \\
\text { family. This kinase } \\
\text { has been shown to } \\
\text { specifically activate } \\
\text { MAPK8/JNK. }\end{array}$ & $\begin{array}{l}\text { GO annotations connected } \\
\text { to this gene: transferase } \\
\text { activity, transferring } \\
\text { phosphorus-containing } \\
\text { groups and protein } \\
\text { tyrosine kinase activity. }\end{array}$ \\
\hline $\begin{array}{l}\text { MAPK11 } \\
\text { (Mitogen- } \\
\text { Activated Protein } \\
\text { Kinase 11) }\end{array}$ & 0.33 & 0.43 & $\begin{array}{l}\text { It is involved in the } \\
\text { integration of } \\
\text { biochemical signals } \\
\text { for a wide variety of } \\
\text { cellular processes, } \\
\text { including cell } \\
\text { proliferation, } \\
\text { differentiatio, and } \\
\text { development. }\end{array}$ & $\begin{array}{l}\text { GO annotations connected } \\
\text { to this gene: transferase } \\
\text { activity, transferring } \\
\text { phosphorus-containing } \\
\text { groups and protein } \\
\text { tyrosine kinase activity. }\end{array}$ \\
\hline $\begin{array}{l}\text { APOBEC3F } \\
\text { (Apolipoprotein B } \\
\text { MRNA Editing } \\
\text { Enzyme Catalytic } \\
\text { Subunit 3F) }\end{array}$ & 0.39 & 0.43 & $\begin{array}{l}\text { It is a member of the } \\
\text { cytidine deaminase } \\
\text { gene family. }\end{array}$ & $\begin{array}{l}\text { GO annotations connected } \\
\text { to this gene: poly }(A) R N A \\
\text { binding and hydrolase } \\
\text { activity, acting on carbon- } \\
\text { nitrogen (but not peptide) } \\
\text { bonds, in cyclic amidines. }\end{array}$ \\
\hline $\begin{array}{l}\text { APOBEC3D } \\
\text { (Apolipoprotein B } \\
\text { MRNA Editing } \\
\text { Enzyme Catalytic } \\
\text { Subunit 3D) } \\
\end{array}$ & 0.31 & 0.38 & $\begin{array}{l}\text { It is a member of the } \\
\text { cytidine deaminase } \\
\text { gene family. }\end{array}$ & $\begin{array}{l}\text { GO annotations connected } \\
\text { to this gene: hydrolase } \\
\text { activity, acting on carbon- } \\
\text { nitrogen (but not peptide) } \\
\text { bonds, in cyclic amidines. }\end{array}$ \\
\hline
\end{tabular}


Table 2: Genetic profiling of the most significant negatively correlated genes with HOXD8 performed by The Cancer Genome Atlas (TCGA).

\begin{tabular}{|l|l|l|l|l|}
\hline Correlated gene & $\begin{array}{l}\text { Pearson's } \\
\text { Correlation }\end{array}$ & $\begin{array}{l}\text { Spearman's } \\
\text { Correlation }\end{array}$ & Entrez Gene & GeneCards \\
\hline $\begin{array}{l}\text { STK38 } \\
\text { (Serine/Threonine } \\
\text { Kinase 38) }\end{array}$ & -0.31 & -0.39 & $\begin{array}{l}\text { The encoded protein has } \\
\text { been shown to function } \\
\text { in the cell cycle and } \\
\text { apoptosis. This protein } \\
\text { has also been found to } \\
\text { regulate the protein } \\
\text { stability and } \\
\text { transcriptional activity } \\
\text { of the MYC oncogene. }\end{array}$ & $\begin{array}{l}\text { GO annotations connected } \\
\text { to this gene: transferase } \\
\text { activity, transferring } \\
\text { phosphorus } \text { containing } \\
\text { groups and protein } \\
\text { tyrosine kinase activity. }\end{array}$ \\
\hline $\begin{array}{l}\text { GPD1L (Glycerol- } \\
\text { 3-Phosphate } \\
\begin{array}{l}\text { Dehydrogenase 1- } \\
\text { Like) }\end{array}\end{array}$ & -0.36 & -0.41 & $\begin{array}{l}\text { found in the cytoplasm, } \\
\text { associated with the } \\
\text { plasma membrane, } \\
\text { where it binds the } \\
\text { sodium channel, voltage- } \\
\text { gated, type V, alpha } \\
\text { subunit (SCN5A). }\end{array}$ & $\begin{array}{l}\text { GO annotations connected } \\
\text { to this gene: protein } \\
\text { homodimerization activity } \\
\text { and NAD binding. }\end{array}$ \\
\hline $\begin{array}{l}\text { LRRFIP2 (LRR } \\
\text { Binding FLII } \\
\text { Interacting } \\
\text { Protein 2) }\end{array}$ & -0.33 & -0.36 & Not available & $\begin{array}{l}\text { GO annotations connected } \\
\text { to this gene: protein } \\
\text { dimerization activity and } \\
\text { LRR domain binding. }\end{array}$ \\
\hline $\begin{array}{l}\text { FAM84A (Family } \\
\text { With Sequence } \\
\text { Similarity 84 } \\
\text { Member A }\end{array}$ & -0.35 & -0.38 & Not available & Protein Coding gene. \\
\hline $\begin{array}{l}\text { DoK4 (Docking } \\
\text { Protein 4) }\end{array}$ & -0.31 & & Not available & $\begin{array}{l}\text { GO annotations connected } \\
\text { to this gene: receptor } \\
\text { signaling protein activity } \\
\text { and insulin receptor } \\
\text { binding. }\end{array}$ \\
\hline
\end{tabular}

